\title{
FISCAL SPACE AND INCREASING FISCAL RESILIENCE
}

Joshua Aizenman, Yothin Jinjarak, Hien Thi Kim Nguyen, and Donghyun Park

\section{NO. 582}

May 2019

\section{ADB ECONOMICS WORKING PAPER SERIES}


ADB Economics Working Paper Series

\section{Fiscal Space and Increasing Fiscal Resilience}

Joshua Aizenman, Yothin Jinjarak, Hien Thi Kim Nguyen, and Donghyun Park

No. 582 | May 2019
Joshua Aizenman (aizenman@usc.edu) is Dockson Chair in Economics and International Relations in the University of Southern California and Research Associate at the National Bureau of Economic Research. Yothin Jinjarak (yothin.jinjarak@vuw.ac.nz) is Associate Professor and Hien Thi Kim Nguyen (hien.nguyen@vuw.ac.nz) is a PhD student in economics at the Victoria University of Wellington. Donghyun Park (dpark@adb.org) is Principal Economist at the Asian Development Bank (ADB).

We gratefully acknowledge the useful comments of Luc Eyraud, Madhavi Pundit, Mark Spiegel, and the participants of the Maintaining Macroeconomic Stability in the Current Global Environment workshop in ADB on 30-31 May 2018 and the Asia-Pacific Economic Association 2018

Conference at the University of Southern California on 3-4 August 2018. 
(C) 2019 Asian Development Bank 6 ADB Avenue, Mandaluyong City, 1550 Metro Manila, Philippines

Tel +632632 4444; Fax +6326362444

www.adb.org

Some rights reserved. Published in 2019.

ISSN 2313-6537 (print), 2313-6545 (electronic)

Publication Stock No. WPS190162-2

DOI: http://dx.doi.org/10.22617/WPS190162-2

The views expressed in this publication are those of the authors and do not necessarily reflect the views and policies of the Asian Development Bank (ADB) or its Board of Governors or the governments they represent.

ADB does not guarantee the accuracy of the data included in this publication and accepts no responsibility for any consequence of their use. The mention of specific companies or products of manufacturers does not imply that they are endorsed or recommended by ADB in preference to others of a similar nature that are not mentioned.

By making any designation of or reference to a particular territory or geographic area, or by using the term "country" in this document, $A D B$ does not intend to make any judgments as to the legal or other status of any territory or area.

This work is available under the Creative Commons Attribution 3.0 IGO license (CC BY 3.0 IGO)

https://creativecommons.org/licenses/by/3.o/igo/. By using the content of this publication, you agree to be bound by the terms of this license. For attribution, translations, adaptations, and permissions, please read the provisions and terms of use at https://www.adb.org/terms-use\#openaccess.

This CC license does not apply to non-ADB copyright materials in this publication. If the material is attributed to another source, please contact the copyright owner or publisher of that source for permission to reproduce it. $\mathrm{ADB}$ cannot be held liable for any claims that arise as a result of your use of the material.

Please contact pubsmarketing@adb.org if you have questions or comments with respect to content, or if you wish to obtain copyright permission for your intended use that does not fall within these terms, or for permission to use the ADB logo.

Corrigenda to ADB publications may be found at http://www.adb.org/publications/corrigenda.

Note:

In this publication, “\$” refers to United States dollars.

The ADB Economics Working Paper Series presents data, information, and/or findings from ongoing research and studies to encourage exchange of ideas and to elicit comment and feedback about development issues in Asia and the Pacific. Since papers in this series are intended for quick and easy dissemination, the content may or may not be fully edited and may later be modified for final publication. 


\section{CONTENTS}

TABLES AND FIGURES iv

ABSTRACT V V

$\begin{array}{ll}\text { I. INTRODUCTION } & 1\end{array}$

II. EMPIRICAL ANALYSIS

A. Data and Empirical Specifications 4

B. $\quad$ Results: Government-Spending Cyclicality and Its Determinants 6

III. ECONOMIC SIGNIFICANCE AND POLICY IMPLICATIONS

A. Baseline $\quad 12$

B. Fiscal Space in a Deteriorating Macroeconomic Environment 21

C. Fiscal Cyclicality in Good Times versus Bad Times 23

D. Cyclicality of Government Spending with Capital Investment 26

E. Sovereign Wealth Funds and Government-Spending Cyclicality 29

$\begin{array}{ll}\text { IV. CONCLUSIONS } & 31\end{array}$

$\begin{array}{ll}\text { APPENDIX } & 33\end{array}$

$\begin{array}{ll}\text { REFERENCES } & 35\end{array}$ 


\section{TABLES AND FIGURES}

\section{TABLES}

1 Cross-Country Regression of Fiscal Cyclicality Using Prais-Winsten Estimates, 1960-2016 8

2 Cross-Country Regression of Fiscal Cyclicality Using Ordinary Least Squares Estimates, 10 1960-2016

3 Government-Spending Behavior in OECD and Non-OECD Countries 13

$4 \quad$ Government-Spending Behavior by Income 14

$5 \quad$ Time-Varying Behavior of Government Spending 15

6 Cross-Country Regression of Fiscal Cyclicality Using Prais-Winsten Estimates, 1980-2016 27

7 Sovereign Wealth Funds and Government-Spending Cyclicality 30

\section{FIGURES}

1 Ratio of Public Debt to Gross Domestic Product in Advanced Economies and

Emerging Markets

$2 \quad$ Government-Spending Cyclicality $\widehat{\beta}_{\mathrm{GS}}$ by Region and Income, 1960-2016 7

3 Economic Significance of Variables to Government-Spending Cyclicality $\widehat{\beta}_{\mathrm{GS}}, 1960-2016 \quad 17$

4 Economic Significance of Variables to Government-Spending Cyclicality $\widehat{\beta}_{\mathrm{GS}} \quad 18$ by Region

$5 \quad$ Economic Significance of Public Debt-Tax Base Ratio to Government-Spending 21 Cyclicality $\widehat{\beta}_{\mathrm{GS}}$ by Region

6 Economic Significance of Public Debt-Tax Base Ratio to Government-Spending 22 Cyclicality $\widehat{\beta}_{\mathrm{GS}}$ by Country

$7 \quad$ Economic Significance of Variables to Government-Spending Cyclicality $\beta_{\mathrm{GS}} \quad 24$ in Good and Bad Times 


\begin{abstract}
The paper compares fiscal cyclicality across regions and countries from 1960 to 2016. It finds that more than half of 170 countries analyzed in seven regions had, in more recent years, limited fiscal space, and that their fiscal policy was either cyclical or procyclical. This was particularly apparent since the 2008-2009 global financial crisis, which was marked by increased procyclical government spending when accounting for net acquisition of nonfinancial assets and capital expenditure. We construct a limited-fiscal-capacity statistic, measured by public debt-average tax revenue ratio and its volatility, which is found to be positively associated with fiscal procyclicality. The cyclicality is asymmetric: on average, a more indebted government (relative to the tax base) spends more in good times and cuts back spending indifferently compared with low-debt countries in bad times. Having sovereign wealth funds is also associated with larger countercyclicality. An enduring interest rate rise entails diminished fiscal space-a 10\% increase in the public debt-tax base ratio is associated with an upper bound of a $5.6 \%$ increase in government-spending procyclicality.
\end{abstract}

Keywords: cross-country analysis, fiscal cyclicality, public debt

JEL codes: E02, E62, F40 


\section{INTRODUCTION}

The 2008-2009 global financial crisis focused attention on unsustainable leverage growth as a major contributing factor to the growing financial fragility associated with "bubbly" dynamics. Essentially, a prolonged appreciation of financial and real estate markets increases vulnerability to sharp assetvaluation corrections. A deep enough correction may trigger banking crises and fire-sale dynamics, potentially pushing an economy into a prolonged depression and exposing it to increased social and political instability. ${ }^{1}$ Concerns about reliving another Great Depression explain the complex set of policies implemented by the United States (US) and other countries in the aftermath of the global financial crisis. This resulted in a massive infusion of liquidity to support financial and banking systems, and to bail out systemic banks and prime creditors. The forced deleverage of private borrowers, and the growing fear of a prolonged recession, induced higher household savings and lower investment, further deepening recessionary forces.

To counter these forces, many countries experimented with fiscal stimuli aimed at mitigating deepening recessions. Stabilizing banking and financial systems, in addition to the stimuli, ended up sharply raising the ratio of countries' public debt to gross domestic product (GDP). This pushed the ratio in advanced countries to above 100\% (Figure 1). Similar trends were seen in emerging market economies (EMEs), driving their public debt-GDP ratios higher, with some reaching well above $50 \%$. Even though the average public debt-GDP ratio of EMEs is below that of the Organisation for Economic Co-operation and Development (OECD) countries, their lower tax base-GDP ratios and the higher interest rates paid on their debt (due to sovereign risk premiums) imply a rising fragility of EMEs compared with OECD countries. Because of this, accounting for the tax base and the ratio of public debt to average tax base may be a more informative measure of the fiscal burden associated with the stock of public debt even though the public debt-GDP ratio is used frequently in policy discussions (Aizenman and Jinjarak 2011). Henceforth, we refer to this fiscal measure as limited fiscal space.

Importantly, the economic trajectory since the global financial crisis failed to deal with leverage concerns. The International Monetary Fund observed that "at $\$ 164$ trillion-equivalent to 225\% of global GDP-global debt continues to hit new record highs almost a decade after the collapse of Lehman Brothers. Compared with the previous peak in 2009, the world is now $12 \%$ of GDP deeper in debt, reflecting a pickup in both public and nonfinancial private sector debt after a short hiatus. All income groups have experienced increases in total debt, but, by far, EMEs are in the lead." (International Monetary Fund 2018). In other words, stabilizing a crisis triggered by unsustainable leverage growth in turn contributed to a potentially untenable increase in leverage-to-GDP ratios.

Since 2008, the monetary easing associated with Federal Reserve and European Central Bank policies has led to an unprecedented decline in policy interest rates and risk premiums. These developments markedly reduced the flow costs of serving rising public and private debt, thereby masking the increasing fragility caused by the rising aggregate leverage-GDP ratio. That period has now passed. The so far robust recovery of the US, the gradual unwinding of the Federal Reserve's balance sheet, the projected upward trajectory of the federal funds rate, and the recovery of the euro area will impose growing fiscal challenges that will test countries' fiscal space and their ability to cope with projected higher interest rates by raising their resilience.

1 See Minsky (1992) for the financial instability hypothesis, which analyzed financial market fragility over the life cycle of an economy with speculative investment bubbles endogenous to financial markets. Rajan (2006) pointed out that banking deregulation since the 1980s has increased leverage and risk taking, contributing to a greater exposure to financial stability associated with tail risks. Schularick and Taylor (2012) and Jordà, Schularick, and Taylor (2013) provided empirical evidence linking leverage, business cycles, and crises. 
A key resilience margin is securing fiscal space-that is, the fiscal capacity of countercyclical policy aimed at mitigating business cycles and preventing a prolonged depression after financial crises (Auerbach 2011, Ostry et al. 2010). ${ }^{2}$ Remarkably, in the 2 decades before the global financial crisis, a growing share of fiscal policies in developing countries and EMEs graduated from procyclicality and became countercyclical (Frankel 2011; Frankel, Végh, and Vuletin 2013). Cross-country studies offer several explanations. Woo (2009) presented some evidence showing that social polarization, as measured by income and education inequality, is consistently and positively associated with fiscal procyclicality, controlling for other determinants. And there is also a robust negative impact of fiscal procyclicality on economic growth. Aizenman and Jinjarak (2012) found that higher income inequality is strongly associated with a lower tax base, lower de facto fiscal space, and higher sovereign spreads. Végh and Vuletin (2015) found that tax policy is less procyclical and more countercyclical in countries with better institutional quality and that are more financially integrated (that is, tax and spending policies are conducted in a symmetric way over the business cycle). ${ }^{3}$

\section{Figure 1: Ratio of Public Debt to Gross Domestic Product in Advanced Economies and Emerging Markets}

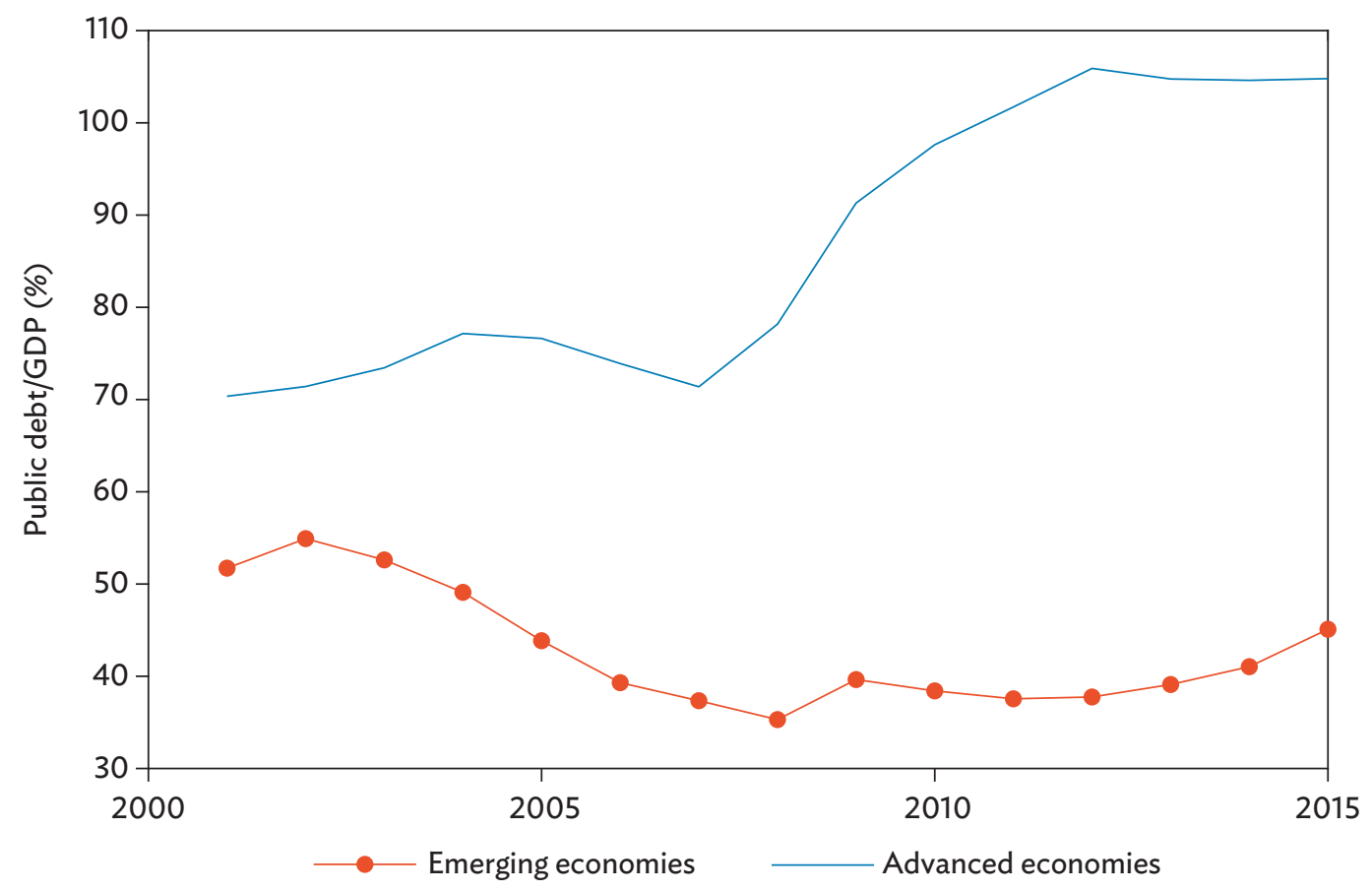

GDP = gross domestic product.

Source:s World Economic Outlook and authors' calculation.

2 See also Gavin et al. (1996) on the identification of fiscal procyclicality as a major amplifier of developing countries' vulnerability to shocks.

3 Related strands of the literature examine fiscal multipliers; for example, Ramey and Zubairy (2018); Leeper, Traum, and Walker (2017); and Ilzetzki, Mendoza, and Végh (2013). For fiscal rules, see Budina et al. (2012); for large fiscal adjustments, see Alesina, Favero, and Giavazzi. (2015). Empirically, fiscal cyclicality, fiscal multipliers, fiscal rules, and large fiscal adjustments are intertwined issues, and their relationships remain an open question and a challenge to address in one go. 
It is against this backdrop that we assess definitions and empirical measures of fiscal cyclicality; compare fiscal cyclicality across countries, including OECD and non-OECD ones, and regions; and identify factors accounting for spending cyclicality patterns. We then link the capacity of countercyclical policy to fiscal space and stage of economic and institutional development, since both are associated with the servicing capabilities of domestic and foreign debt. Our analysis focuses on differences across groups and regions, and examines the role of economic structure (commodity versus manufacturing outputs), financial openness, institutions, and socioeconomic factors (political risks, polarization, and ethnic polarization). We calculate the impact of an enduring interest rate rise on fiscal space, and rank countries and regions by the fragility of their fiscal space to this environment. We close with a discussion of policies that can increase the fiscal resilience of EMEs.

Our study shows a mixed fiscal landscape, where more than half of the 170 countries covered have limited fiscal space, and where fiscal policy is either procyclical or acyclical. More limited fiscal capacity, as measured by the ratio of public debt to 3-year moving average tax revenue and its volatility, are positively associated with fiscal cyclicality, and the public debt-GDP ratio is statistically insignificant in several cases. ${ }^{4}$ This suggests that the public debt-tax base ratio provides a robust fiscal space explanation for studying the cyclicality of government spending. ${ }^{5}$

\section{EMPIRICAL ANALYSIS}

This section presents the data and empirical patterns of fiscal cyclicality across Asia, Latin America, OECD countries, and other regions, comparing the estimates across subperiods from 1960 to 2016. We then explore the determinants of countries' capacities to conduct countercyclical fiscal policy, focusing on tax base, public debt, economic structure, financial openness, and institutional and socioeconomic factors.

Our choice of controlling variables takes into consideration three factors associated with fiscal capacity to conduct countercyclical policy-credit constraints, institutional quality, and tax base variability (these factors are by no means exhaustive and subject to data availability). First, the credit constraints. The elasticity of the supply of funds facing the public sector in recessions is a key determinant of fiscal space. A flatter supply of funds implies an easier countercyclical policy funded by borrowing, which in turn is affected by the presence of buffers (international reserves, sovereign wealth funds), possibly managed by a fiscal rule that allows for more countercyclicality during recessions. Furthermore, low external and internal private and public debt-GDP ratios, as well as the ability to borrow in domestic currency, is associated with greater fiscal space, thereby allowing for cheaper borrowing in bad times.

4 The public debt-tax base ratio in public finance is akin, in the corporate sector, to net debt to earnings before interest depreciation and amortization ratio-also known as the ratio of debt to earnings before interest, taxes, depreciation, and amortization (EBITDA). The ratio of net debt to earnings is a measure of leverage; that is, how many years it would take for a company to pay back its debt if net borrowing is 0 and EBITDA is constant. This measure is frequently used by credit rating agencies.

5 Investopedia says, "Ratios higher than 4 or 5 typically set off alarm bells because this indicates that a company is less likely to be able to handle its debt burden, and thus is less likely to be able to take on the additional debt required to grow the business." https://www.investopedia.com/terms/n/net-debt-to-ebitda-ratio.asp. 
Institutional quality is among the factors that are associated with fiscal space, which also include default history, inflation, and terms-of-trade volatility. In particular, the collection efficiency of tax revenue is affected by the maturity of institutions and the spectrum of taxes. Greater political and ethnic polarization, inequality, and corruption may reduce a population's cooperation to pay their "fair share," thereby making tax collection harder and so increasing sovereign spreads and leading to less fiscal space. Public procyclicality may also be weaker in countries with more progressive taxes and transfers, and more countercyclical infrastructure expenditure, such as the use of infrastructure and housing investment as a countercyclical policy by the People's Republic of China. For tax base variability, the magnitude of revenue procyclicality depends on production structure. A higher commodity share in GDP may be associated with greater exposure to the procyclicality of government revenues. Increased urbanization and international trade are associated with easier collection of taxes, implying that tax compliance is higher and may result in tax revenue procyclicality.

\section{A. Data and Empirical Specifications}

To estimate the empirical patterns of fiscal policy cyclicality and its determinants, we start by using the benchmark framework in the literature; for example, Woo (2009). Two estimation steps are then used for the empirical analysis.

For the first estimation step, we conduct the following time-series regressions to measure the cyclicality of government spending during 1960-2016 by country:

$$
\Delta \log R G S_{i t}=\alpha_{i}+\beta_{i} * \Delta \log R G D P_{i t}+\varepsilon_{i t}
$$

where $i$ and $t$ denote country and year, $\alpha_{i}$ is a constant term, $\varepsilon_{i t}$ is an error term, $R G S$ is real general government final consumption, and $R G D P$ is real GDP. ${ }^{6}$ In this baseline model, we use a standard twostep Prais-Winsten regression to correct for the first-order autocorrelation in the residuals. In the Prais-Winsten approach, the errors are assumed to follow a first-order autoregressive process. Since the structure of error terms is unobservable, we also use ordinary least squares (OLS) with robust standard errors as a further check to address heteroskedasticity.

The literature shows some variation in the estimation of fiscal cyclicality; for example, Lane (2003), Ilzetzki and Végh (2008), Végh and Vuletin (2015), and Aizenman et al. (2018). ${ }^{7}$ Because of data availability, we use real GDP growth instead of the output gap, which is calculated from real output by applying filtering tools (that is, the Hodrick-Prescott, Baxter-King, and Kalman filters). It is also unlikely that the potential output estimation and filtering are commonly applicable across countries. As a bottom line, we aim for an empirical framework that is straightforward and as easy to replicate as possible. To construct the sample, we keep the countries with at least 25 years of data. We deflated nominal general government final consumption and nominal GDP, using the GDP deflator. The main data source is the World Bank's World Development Indicators, which covers 137 countries. We use data from 1960 to 2016. For the other 33 countries without sufficient data, we supplement with information from the International Monetary Fund's International Financial Statistics and World Economic Outlook.

6 Kaminsky, Reinhart, and Végh (2004) suggested that the indicators other than government spending and tax rates are likely to induce ambiguous cyclical behavior of fiscal policy. We provide cross-check results with tax rates cyclicality in our National Bureau of Economic Research working paper (Aizenman et al. 2018).

7 See Table 1 in Aizenman et al. (2018) for a comparison of their methods. 
For the second estimate step, cross-country regression is used to explain governmentspending cyclicality over 1960-2016. We then study the determinants of the estimated cyclicality coefficients, focusing on the measure of limited fiscal capacity and macroeconomic, socioeconomic, and institutional variables as follows:

$$
\hat{\beta}_{i}=\alpha_{0}+\theta_{k} * X_{k i}+\gamma_{i} * \operatorname{CONTROLS} S_{l i}+e_{i}
$$

where $i$ denotes country, $X_{k i}$ includes the main variables of interest (limited fiscal capacity, export structure, country risks), and CONTROLS $S_{\text {Ii }}$ includes macroeconomic and socioeconomic variables (inflation, trade and financial openness, government size [its consumption share in GDP], and political constraints), averaged over 1960-2016. To account for heteroskedascity, we estimate equation (2) by OLS with robust standard errors.

We also address different patterns of serial correlation of the residuals by using OLS with Newey-West standard errors and the endogeneity problem-real GDP may be argued to be endogenous in equation (1) - by using instrumental variables in the first estimation step. ${ }^{8}$ The second estimation step for cross-country regression using an alternative specification-weighted least squares (weight is the inverse of standard errors of estimated government spending cyclicality in the first step)-provides robust results that are not presented in this paper for reasons of space.

A brief explanation on our selection of the determinants is needed. To calculate the ratio of public debt to tax revenue, we use general government tax, including social contributions. To capture its second moments, we calculate the volatility of limited fiscal capacity, using its standard deviation. Since the size of the tax base is persistent in the short to medium term, we add an alternative measure of limited fiscal capacity, using the ratio of public debt to the 3 years moving average of tax revenue. In this estimation, we compare the public debt-tax base with public debtGDP ratios, because fiscal space is a multidimensional concept, exemplified in several fiscal indicators (IMF 2016). To account for socioeconomic and institutional quality, we use several composite risk indicators, including financial, economic, and political conditions in the International Country Risk Guide dataset. We also control for political constraints (the extent to which executives face political constraints in implementing their policies), drawn from Henisz (2002).

8 For excluded instrumental variables, we alternatively use global liquidity shock measured as the real return on 6month Treasury bills weighted by countries' de jure financial openness using Chinn and Ito (2006) index to proxy for a country's exposure to global liquidity; the weighted real GDP growth of trading partners, and the US business cycle defined by the National Bureau of Economic Research weighted by countries' de jure financial openness using Chinn and Ito (2006) index to capture external shocks. Please see Aizenman et al. (2018) for detailed robustness check results. 


\section{B. Results: Government-Spending Cyclicality and Its Determinants}

We estimate government-spending cyclicality based on the country-specific coefficients $\left(\widehat{\beta}_{\mathrm{GS}}\right)$ using the Prais-Winsten estimator. Based on the coefficient signs, we group countries into countercyclicality (6 countries), procyclicality (92 countries), and acyclicality (72 countries), and then examine the key statistics of the most procyclical and the most countercyclical countries in each region based on $\widehat{\beta}_{\mathrm{GS}}$. ${ }^{9}$

Across regions over 1960-2016, the government-spending cyclicality $\widehat{\beta}_{\mathrm{GS}}$ of Sub-Saharan Africa is the highest among the estimates of $\hat{\beta}_{\mathrm{GS}}(0.89$, most procyclical), followed by Latin America and the Caribbean (0.77), Middle East and North Africa (0.69), East Asia and the Pacific (0.46), Europe and Central Asia (0.41), and South Asia (0.35). North America has negative and the lowest estimates of $\widehat{\beta}_{\mathrm{GS}}(-0.25$, most countercyclical). Across income levels, the degree of procyclicality is negatively associated with income level; that is, non-OECD countries, on average, are more fiscally procyclical $\left(0.74\right.$, higher $\left.\hat{\beta}_{\mathrm{GS}}\right)$ than OECD countries $(0.19)$.

Across income levels, low-income countries are most fiscally procyclical (0.93) followed by lower-middle-income countries (0.78), upper-middle-income countries (0.69), and high-income countries (0.32). Non-OECD countries are more fiscally procyclical than OECD ones-0.74 compared with 0.19 . Figure 2 shows the fiscal cyclicality of government spending $\left(\widehat{\beta}_{\mathrm{GS}}\right)$ by geographic region and income level.

What might explain the cross-country differences? Table 1 shows the estimation of fiscal cyclicality coefficients $\left(\widehat{\beta}_{\mathrm{GS}}\right)$ on the socioeconomic and institutional variables over 1960-2016 using Prais-Winsten estimates. The main findings are that political constraints (polcon) are negatively associated with government-spending procyclicality, implying a greater degree of political constraints preventing policy discretions, which in turn limits fiscal procyclicality. Inflation (inf) is positively associated with fiscal procyclicality, suggesting the role of macroeconomic instability, seigniorage, and passive monetary policy. Trade openness (trade) and financial openness (TAL) are negatively associated with fiscal cyclicality, implying that countries are less likely to conduct procyclical fiscal policy if they are more trade and financially open, and that fiscal multipliers are smaller for more open economies.

9 For the detailed statistics, see Aizenman et al. (2018). 
Fiscal Space and Increasing Fiscal Resilience | 7

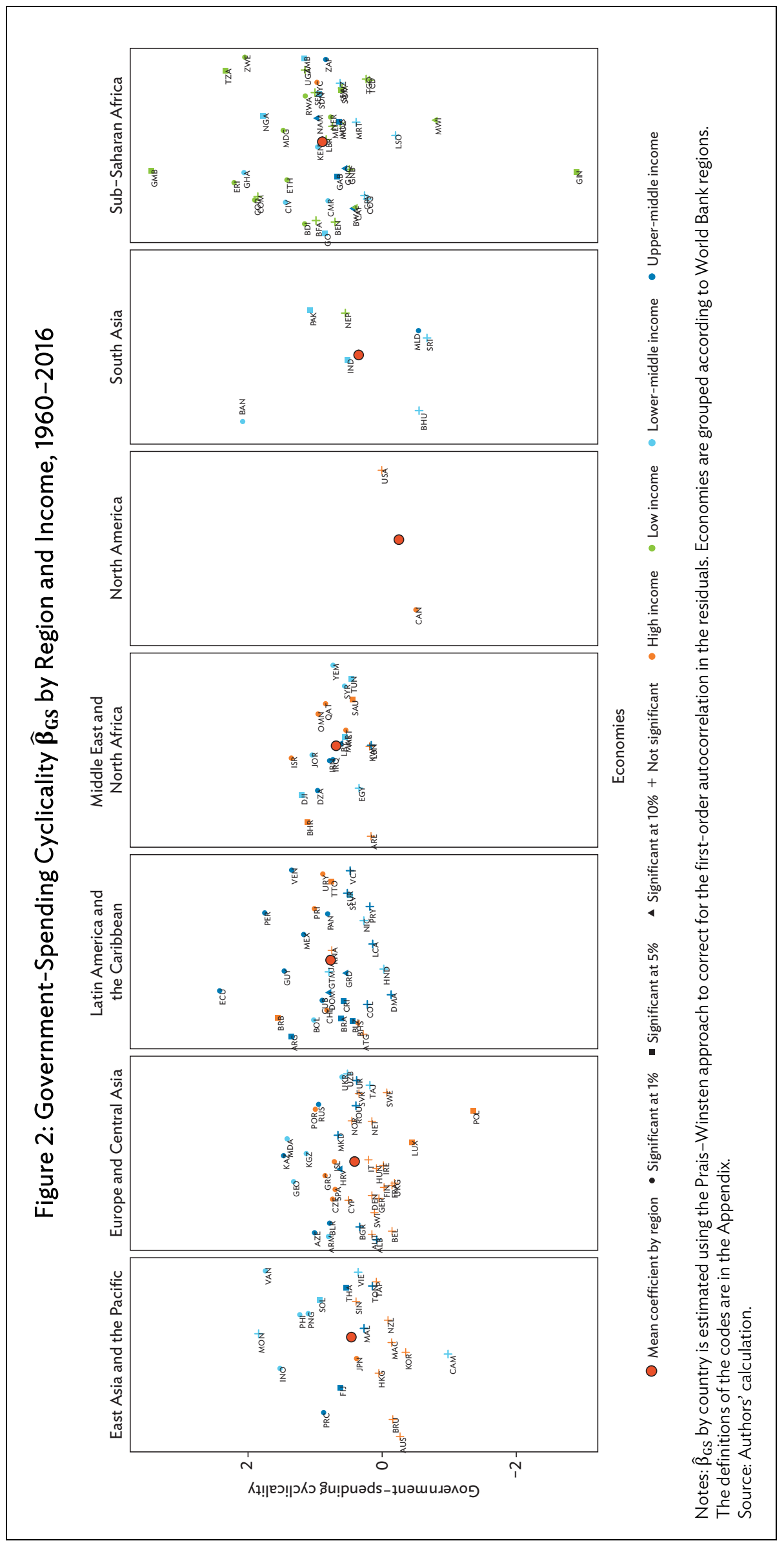







Fiscal Space and Increasing Fiscal Resilience 9

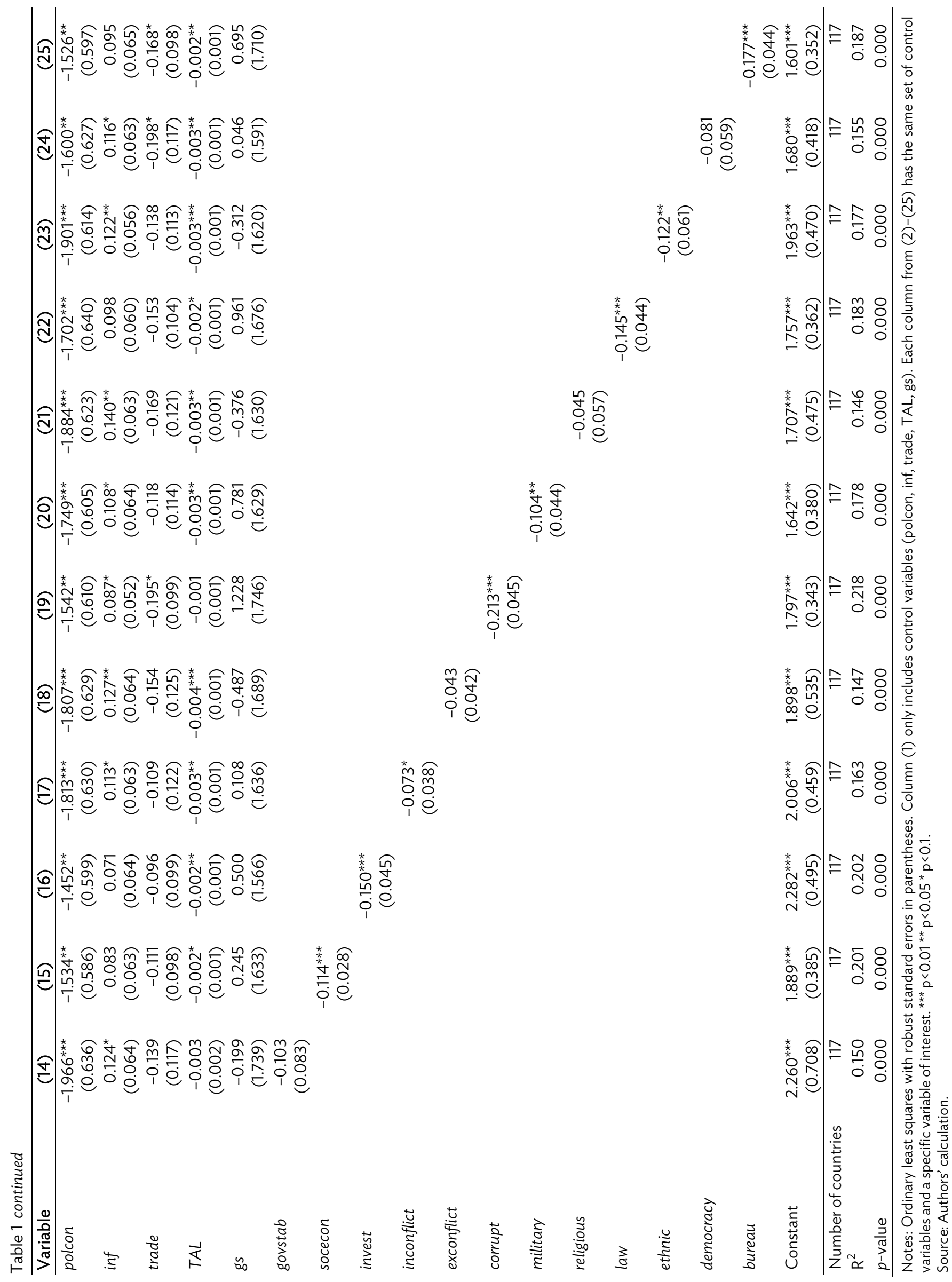




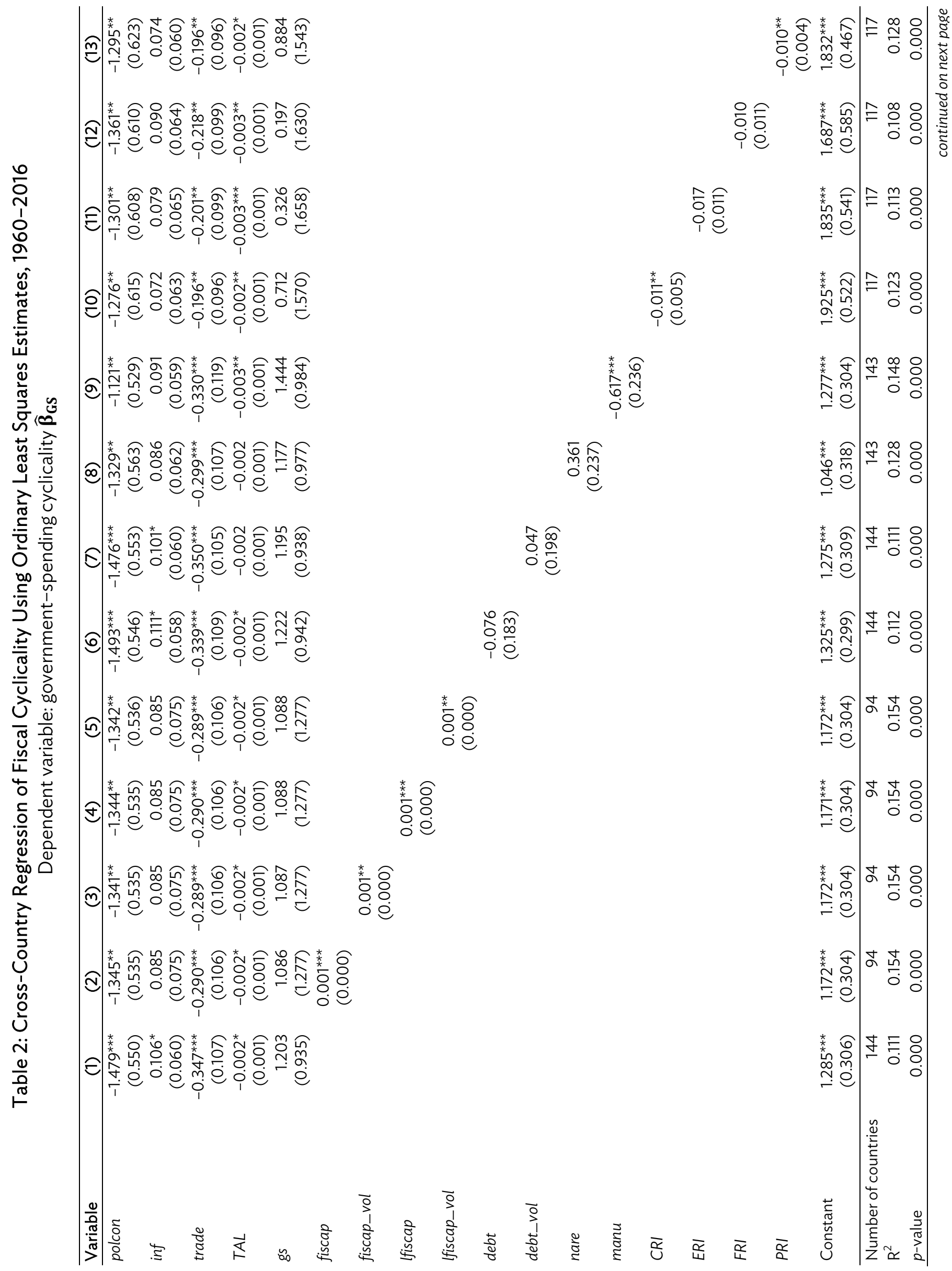




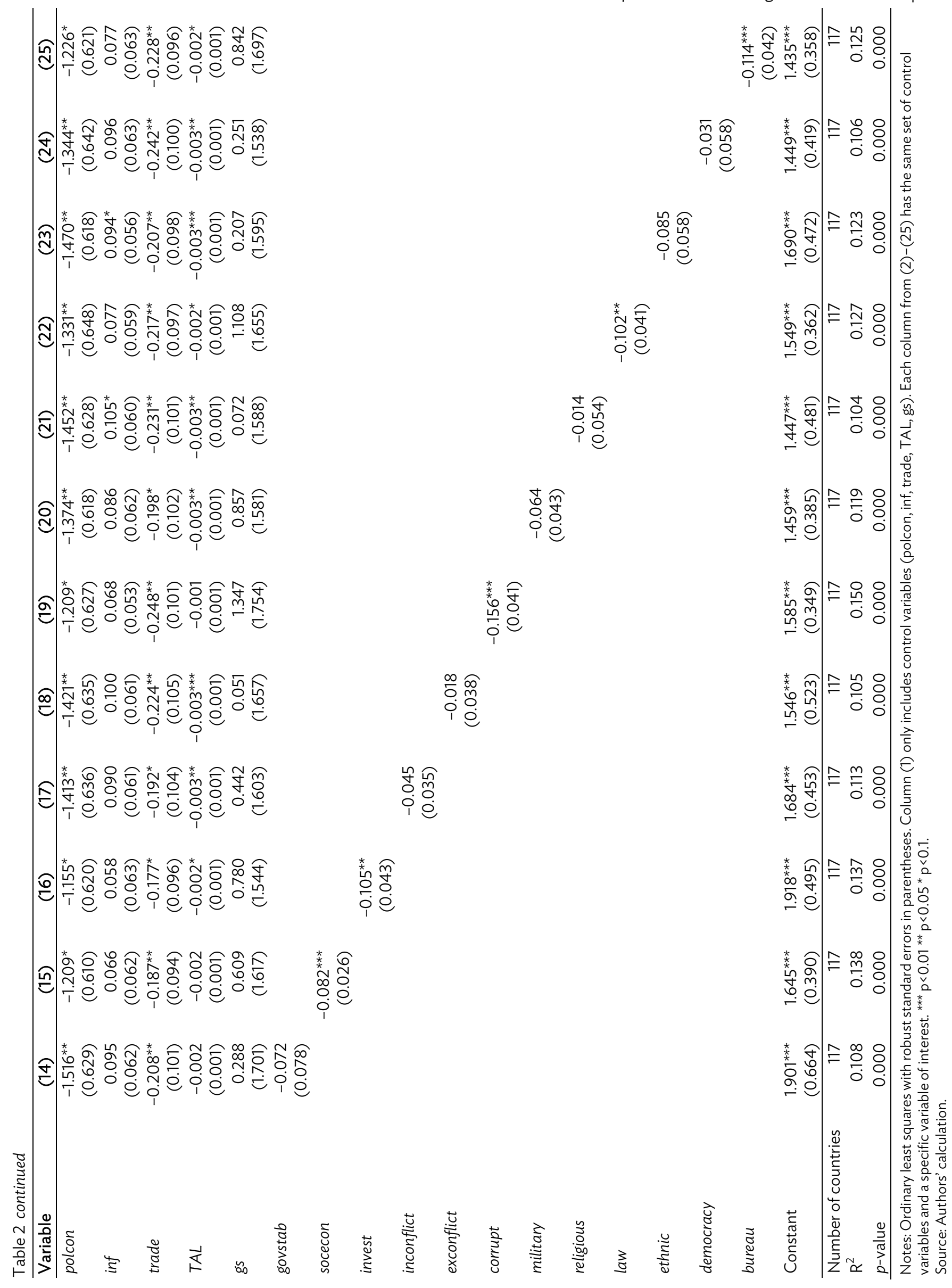


The main findings also show that government size, as measured by its consumption share in GDP (gs), is statistically insignificant in explaining fiscal policy procyclicality; and dropping gs does not affect the robustness of the main results. More limited fiscal capacity, as measured by the public debttax base ratio (fiscal, lfiscap) and its volatility (fiscal_vol, lfiscap_vol) are positively associated with fiscal procyclicality, while the public debt-GDP ratio (debt) and its volatility (debt_vol) are statistically insignificant, suggesting that this ratio provides a robust explanation for government-spending procyclicality in the review period. The manufacturing export share (manu) is negatively associated with fiscal procyclicality, while the natural resource export share (nare) is positive and statistically significant. The composite risk index (CRI), all three component risk indices-economic (ERI), financial (FRI), political (PRI) - and eight out of the 12 political component risk indices are negatively associated with fiscal procyclicality, thus indicating that higher institutional risk is associated with higher fiscal procyclicality. ${ }^{10}$

The country-specific estimated coefficients using OLS estimators are consistent-both qualitatively and quantitatively-with those obtained from the Prais-Winsten estimators. We find three fiscally countercyclical countries, 97 procyclical countries, and 70 acyclical countries. ${ }^{11}$ The ranking of government-spending cyclicality by region, income level, and OECD countries based on OLS estimates is consistent with those of the Prais-Winsten estimates. Most of the associations between socioeconomic and institutional variables with fiscal policy cyclicality based on the OLS ( $\widehat{\beta}_{\mathrm{GS}}$ ) estimators (Table 2 ) are supportive of the Prais-Winsten estimates. Other robustness checks, which are not presented in this paper, also do not influence the main findings. These include robustness checks to address autocorrelation by using OLS Newey-West standard errors, to mitigate endogeneity by using instrumental variables for real GDP in the first estimation step, and to correct for possible biasedness of estimated $\widehat{\beta}_{\mathrm{GS}}$ by using weighted least squares in the second estimation step with the weight being the inverse of standard errors of $\widehat{\beta}_{\mathrm{GS}}$.

\section{ECONOMIC SIGNIFICANCE AND POLICY IMPLICATIONS}

\section{A. Baseline}

\section{Government-Spending Cyclicality by OECD, Non-OECD Countries, and Income Level}

There is no surprise here. Table 3 (left panel) shows government-spending cyclicality in the OECD and non-OECD countries with pooled OLS and fixed effects specifications (controlling for country and year effects) with robust standard errors. During 1960-2016, the non-OECD countries are more procyclical than OECD ones, which is in line with Alesina, Campante, and Tabellini (2008). The results of the panel data estimation of the cyclical patterns of government spending across income groups show that higher-income countries are less fiscally procyclical, followed by middle-income countries and low-income ones (Table 4). This finding is consistent with the panel estimation of OECD countries compared with non-OECD ones and the results from country-specific time series regressions by Aizenman et al. (2018).

10 The eight political component indices negatively associated with government-spending cyclicality are social economic conditions (socecon), investment profile (invest), internal conflict (inconflict), corruption (corrupt), military in politics (military), law and order (law), ethnic tensions (ethnic), and bureaucracy quality (bureau). The four political component indices that are insignificant are government stability (govstab), external conflict (exconflict), religious tensions (religious), and democracy quality (democracy).

11 See Aizenman et al. (2018) for more details. 
Fiscal Space and Increasing Fiscal Resilience | 13

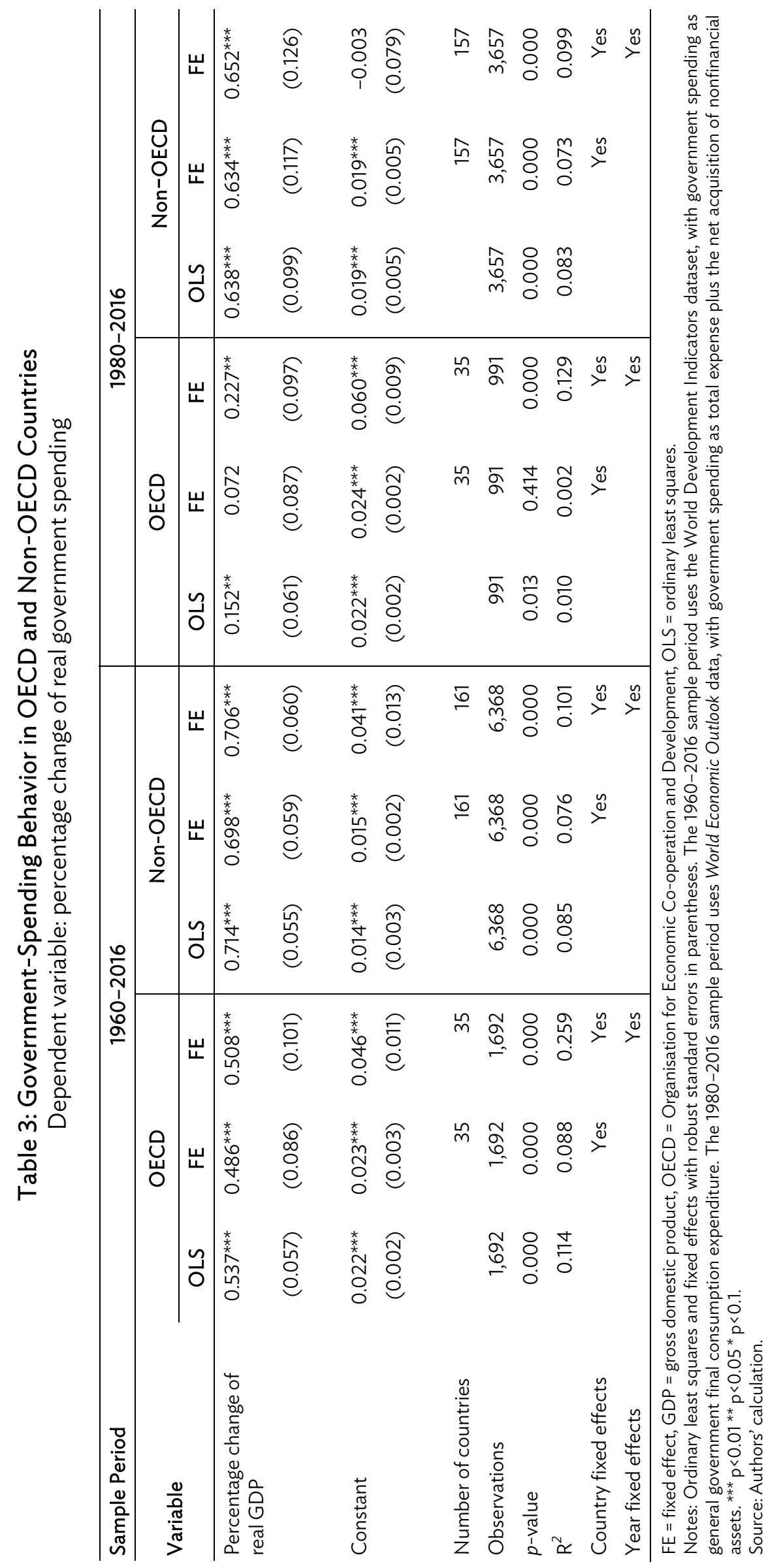




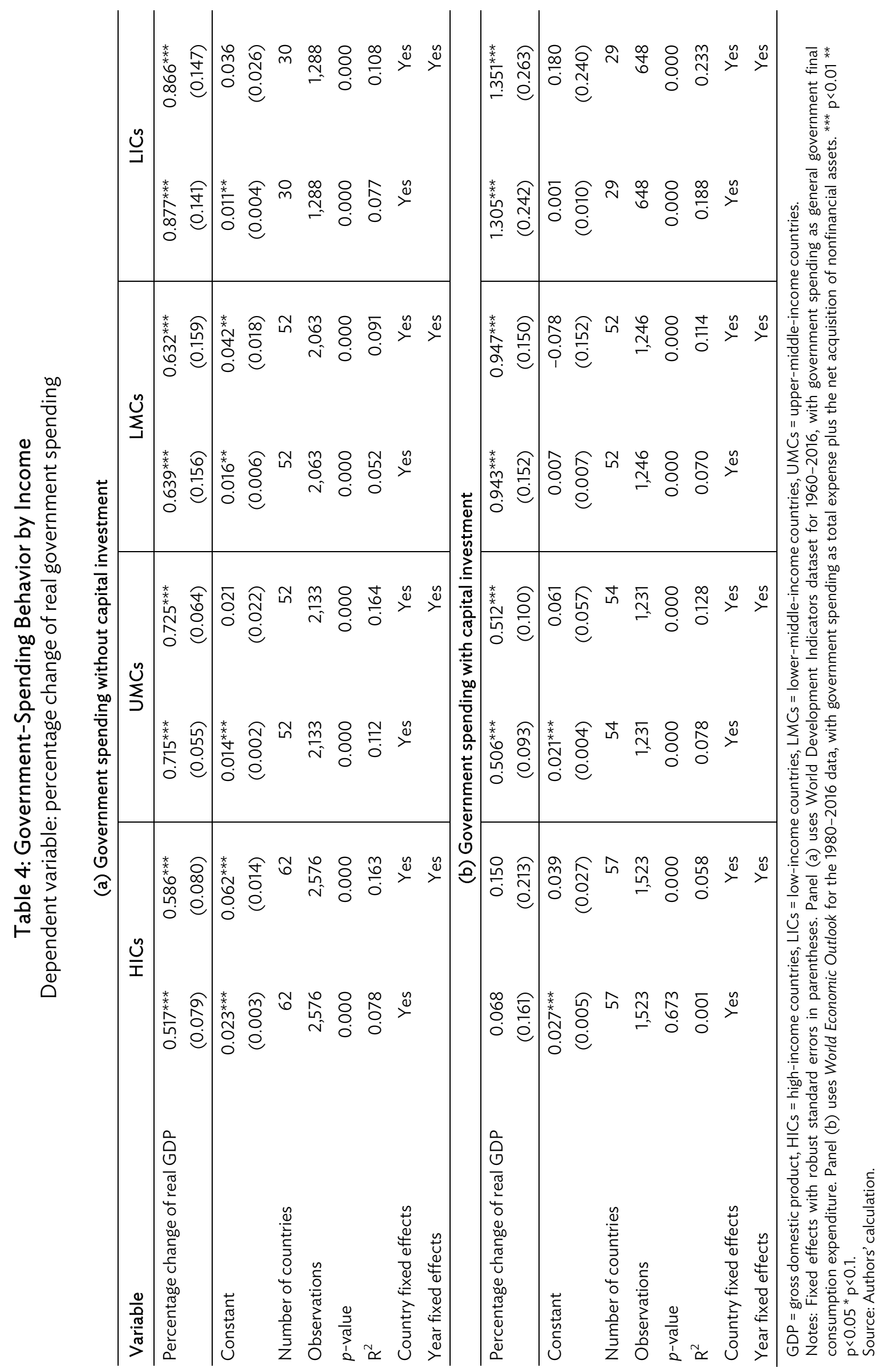




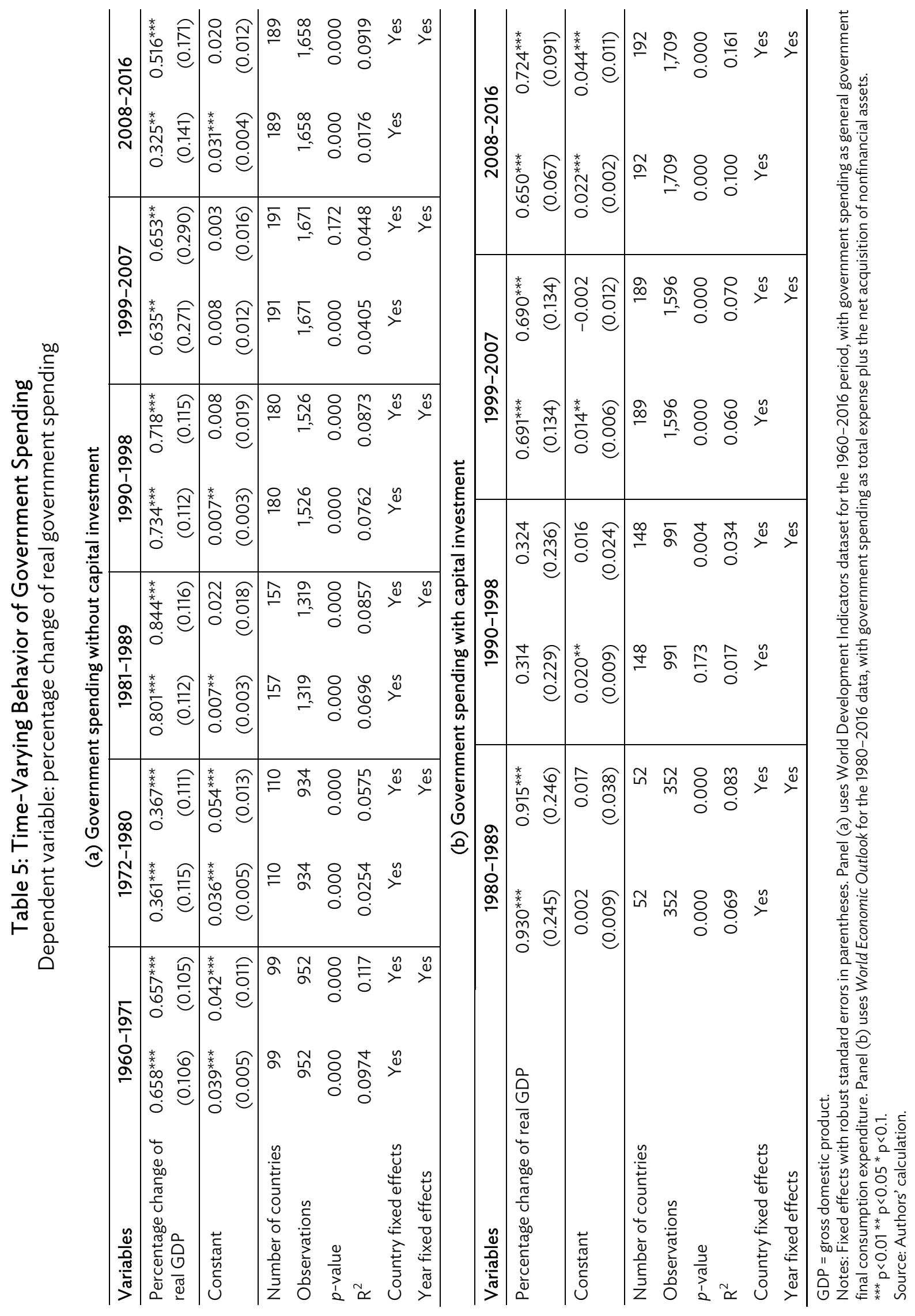




\section{Government-Spending Cyclicality by Subperiod}

What is the time-varying nature of fiscal cyclicality? We find that it matters whether government spending includes or does not include the net acquisition of nonfinancial assets and capital expenditure. Using data from the World Development Indicators, which do not include these items, we find that, on average, the countries in our sample have become less procyclical since the $1980 \mathrm{~s}$. We divided the sample into six subperiods: 1960-1971, 1972-1980, 1981-1989, 1990-1998, 1999-2007, and 2008-2016. Table 5, panel (a), shows that 1981-1989 is characterized by the highest procyclical government-spending levels, followed by 1990-1998, 1999-2007, and 2008-2016. On the basis of this evidence, government-spending cyclicality is on a downward trend.

But this picture changes if we include net acquisition of nonfinancial assets and capital expenditure in government spending. Using government spending data based on the World Economic Outlook's definition, which includes these items, we divided the sample into four subperiods: 19801989, 1990-1998, 1999-2007, and 2008-2016. Table 5, panel (b), shows that the latest period (2008-2016) is no less fiscally procyclical compared with the previous subperiods, controlling for country and year fixed effects. While the procyclicality of the 2008-2016 period is well below the level witnessed in the 1980s, the historic high level of outstanding public debt prevailing at the time of writing may be detrimental to any chance of countercyclical policy in this more unpredictable macroeconomic environment.

\section{Determinant of Government-Spending Cyclicality}

We calculate and rank the economic significance of mainly explanatory variables on governmentspending cyclicality from cross-country regression. The economic significance of each explanatory variable is calculated by multiplying its standard deviation with the estimated coefficient from the regression, thereby approximating the impact of its 1-standard deviation change on the degree of fiscal cyclicality. For government-spending cyclicality, Figure 3 highlights the economic impact of institutional quality (negative), manufacturing export share (negative), natural resource export share (positive), and limited fiscal space (positive), which are consistent in both cases either using PraisWinsten estimates (panel [a]) or OLS estimates (panel [b]).

\section{Determinants of Government-Spending Cyclicality across Regions}

It is clear that the degrees of fiscal cyclicality differ markedly across countries and regions. Given the differences in economic development and the quality of institutions, it is unlikely that we can come up with a sweeping explanation, but we nevertheless give it a try. Here, we repeat the analysis by region to examine the economic significance of each explanatory variable for explaining government-spending cyclicality. North America and South Asia are dropped due to insufficient data, leaving five geographic regions: East Asia and the Pacific, Europe and Central Asia, Latin America and the Caribbean, Middle East and North Africa, and Sub-Saharan Africa. Figure 4 shows the economic impacts by region, focusing on the associations of public debt, export structure, and country risks with governmentspending cyclicality. 
Figure 3: Economic Significance of Variables to Government-Spending Cyclicality $\widehat{\boldsymbol{\beta}}_{\mathrm{GS}}, 1960-2016$

(a) Government-spending cyclicality $\widehat{\boldsymbol{\beta}}_{\mathrm{GS}}$ using Prais-Winsten

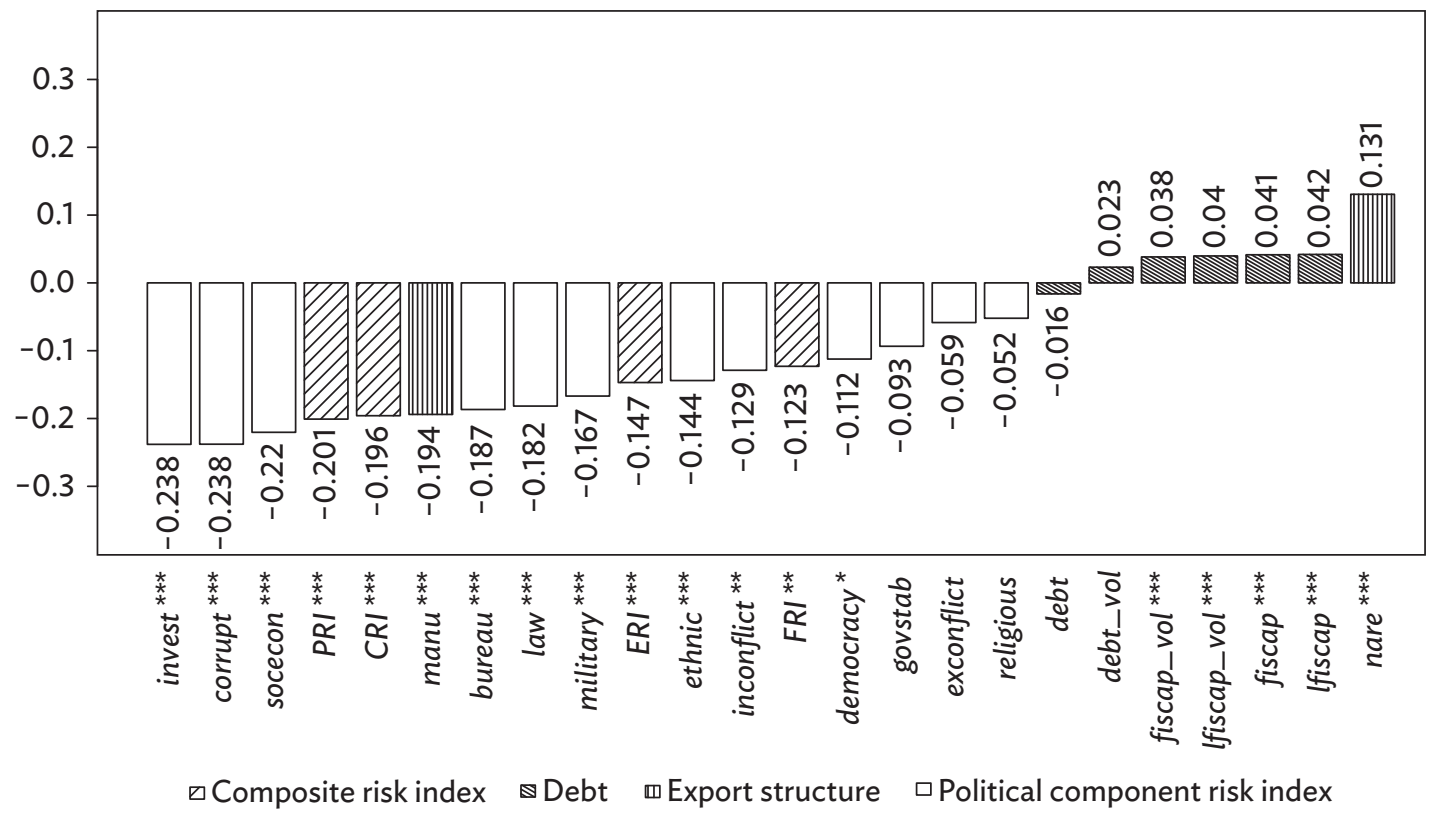

(b) Government-spending cyclicality $\widehat{\boldsymbol{\beta}}_{\mathrm{GS}}$ using ordinary least squares

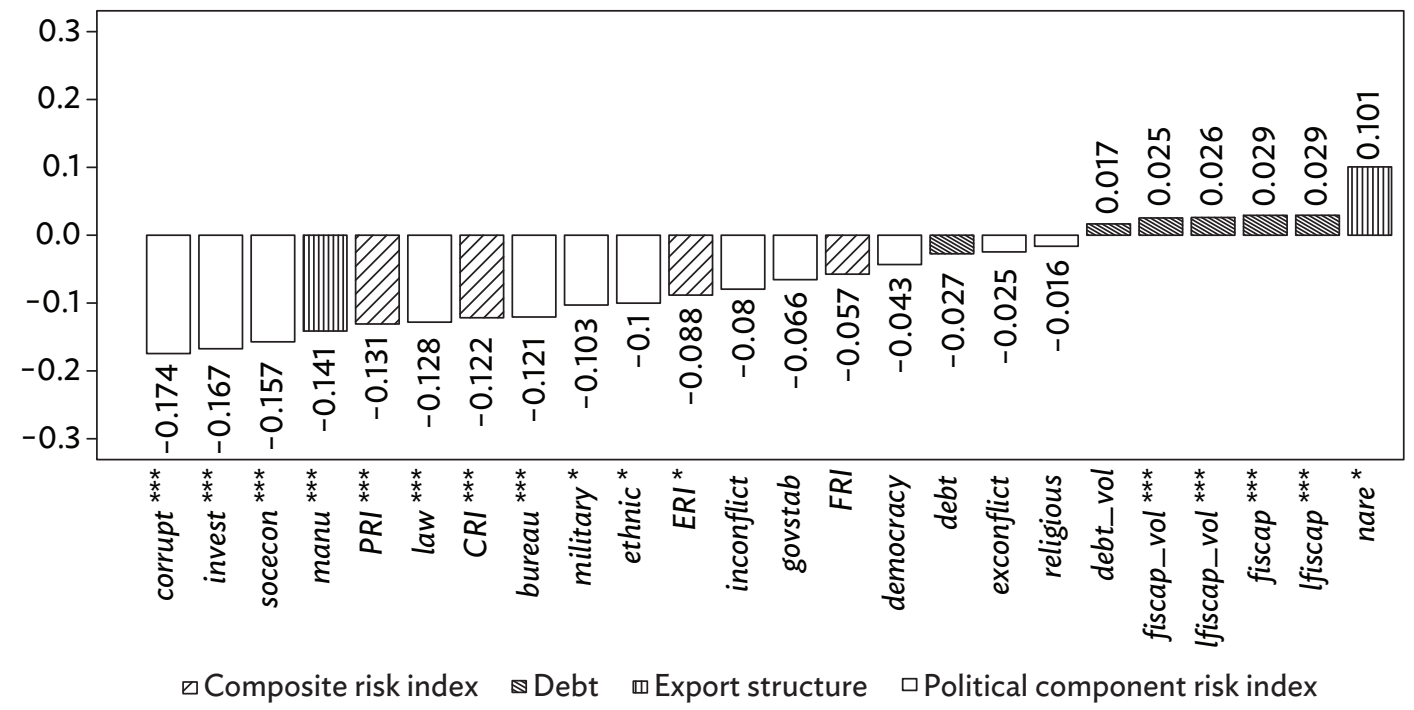

Notes: The economic significance of each explanatory variable is calculated by multiplying its standard deviation with its estimated coefficient to approximate the effect of its 1-standard deviation increase on the fiscal cyclicality. ${ }^{* *} p<0.05^{* *} p<0.01^{*} p<0.2$. 
Figure 4: Economic Significance of Variables to Government-Spending Cyclicality $\widehat{\boldsymbol{\beta}}_{\mathrm{GS}}$ by Region

(a) East Asia and the Pacific

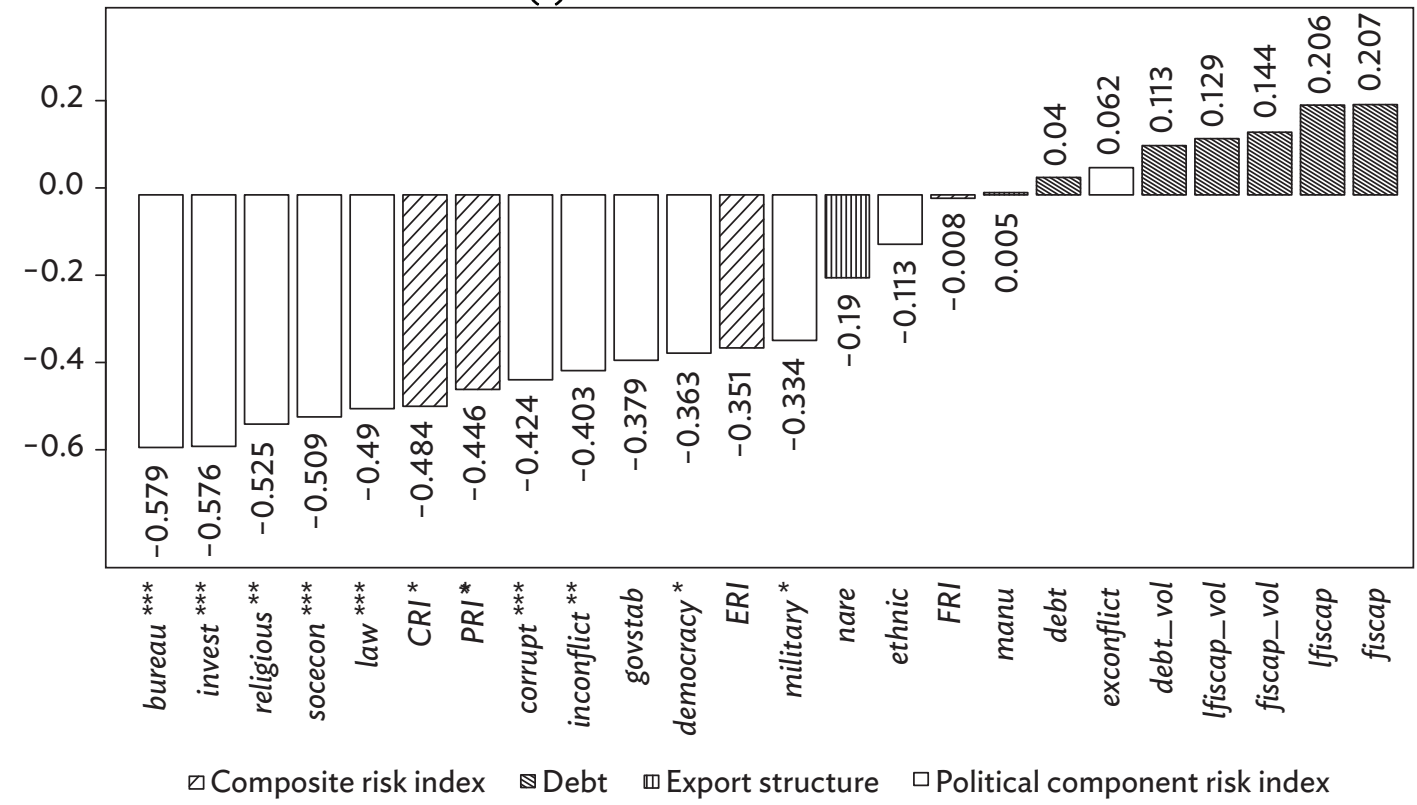

(b) Europe and Central Asia

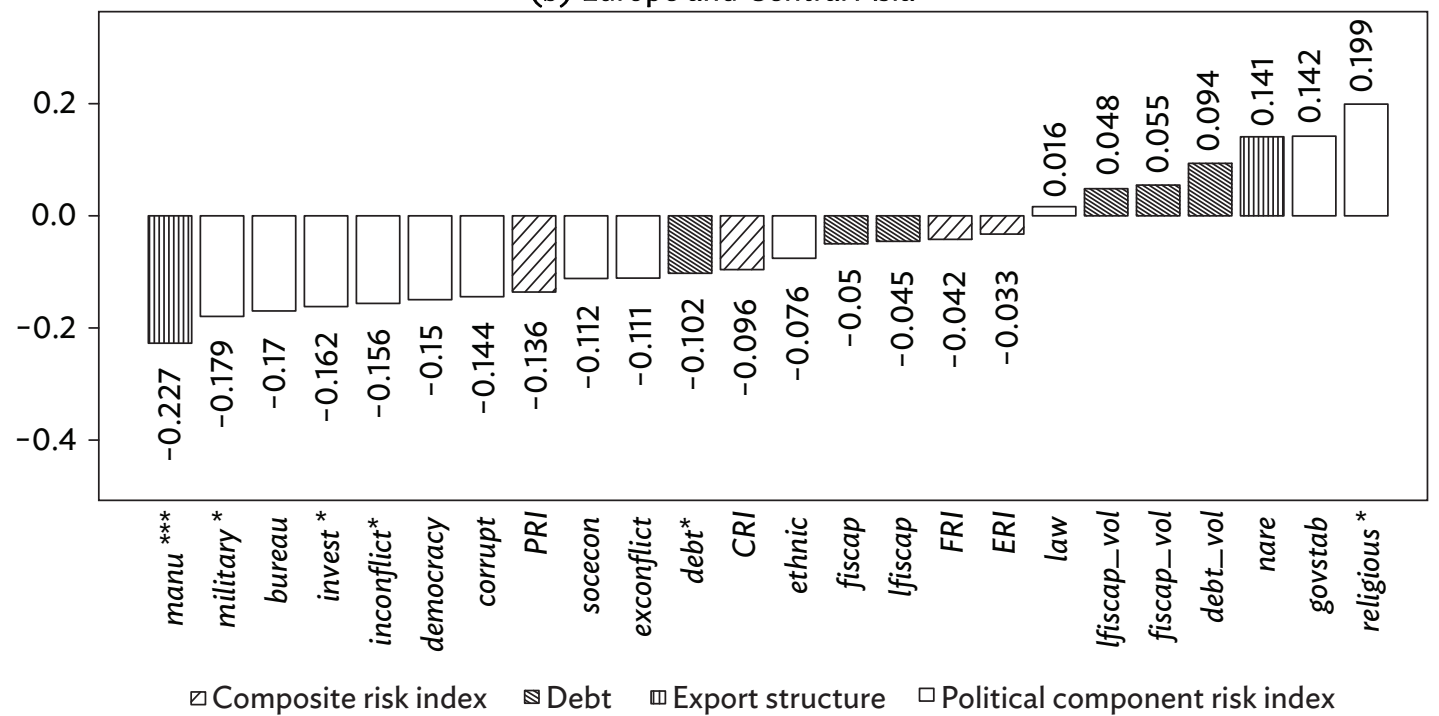


Figure 4 continued

\section{(c) Latin America and the Caribbean}

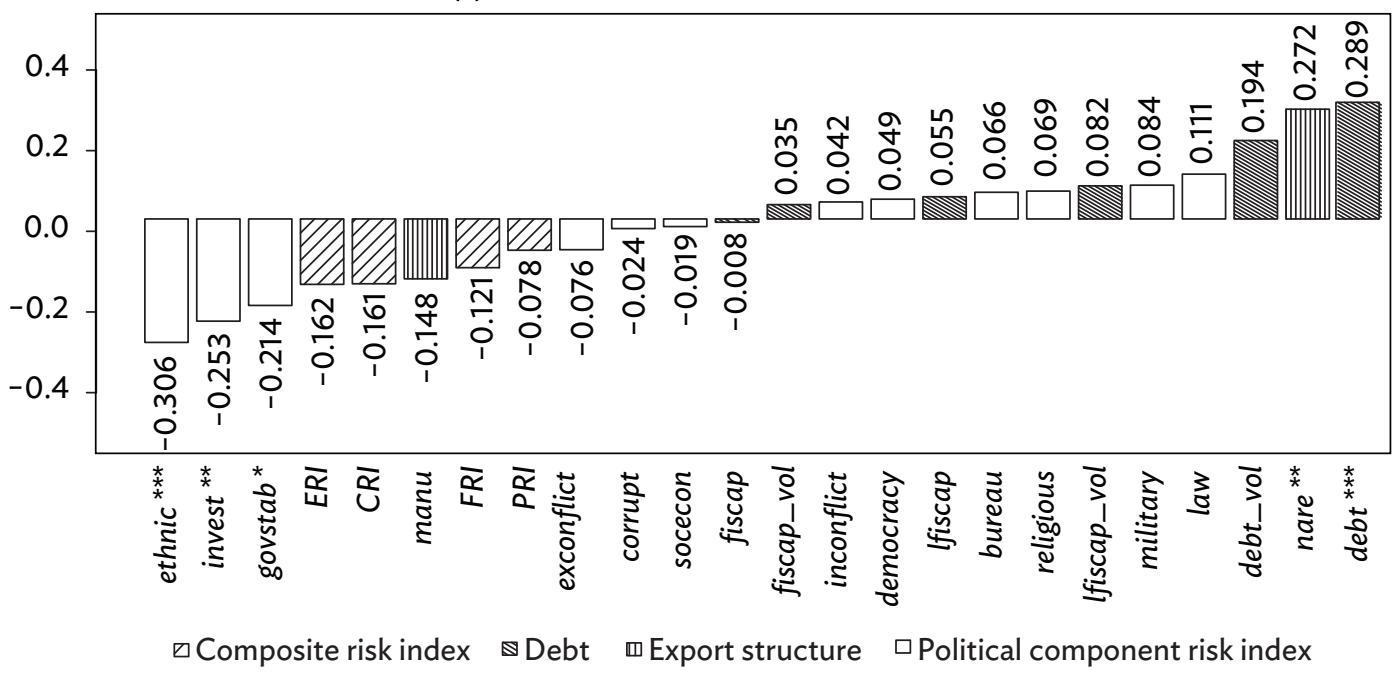

d. Middle East and North Africa

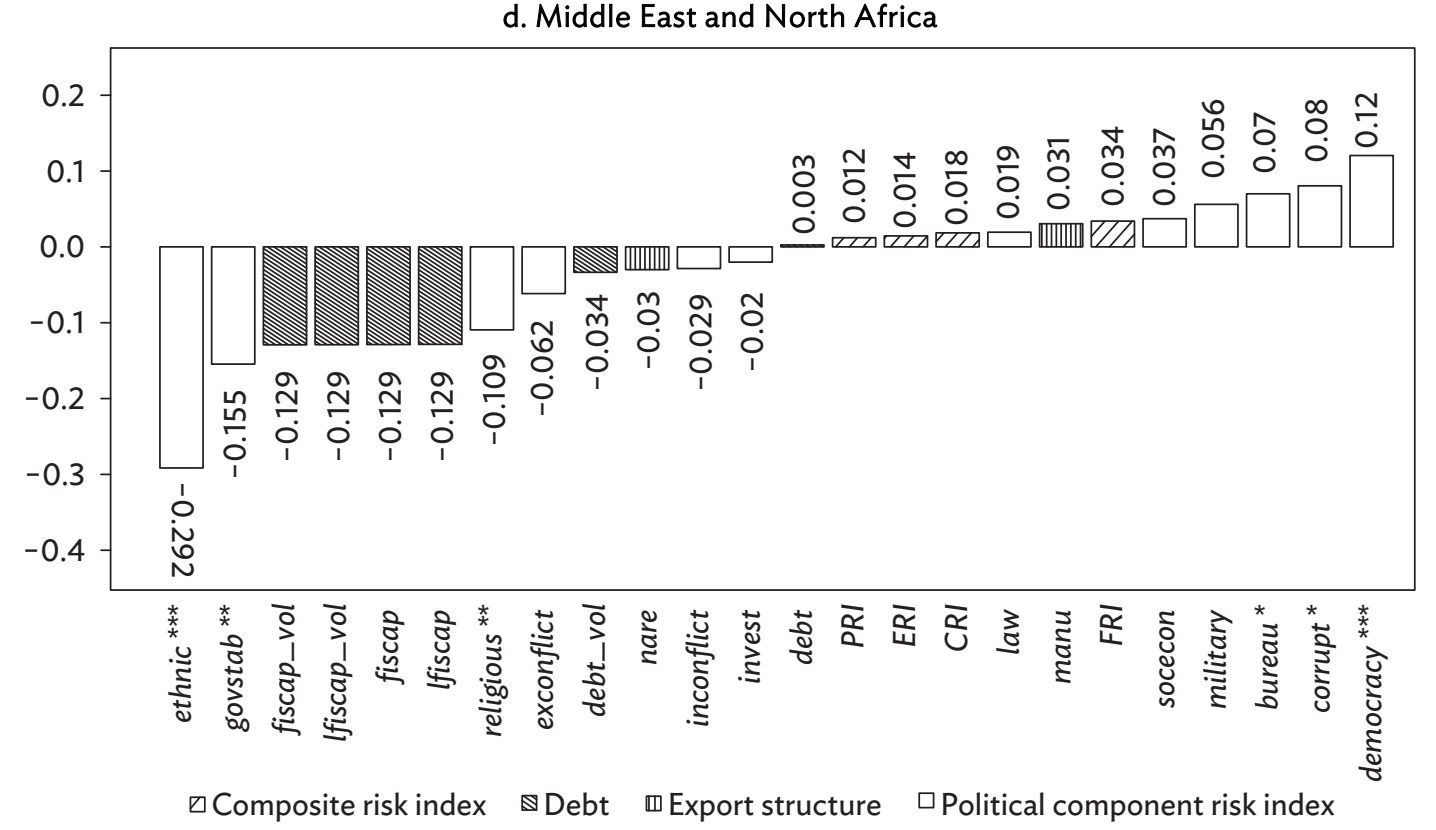

continued on next page 
Figure 4 continued

(e) Sub-Saharan Africa

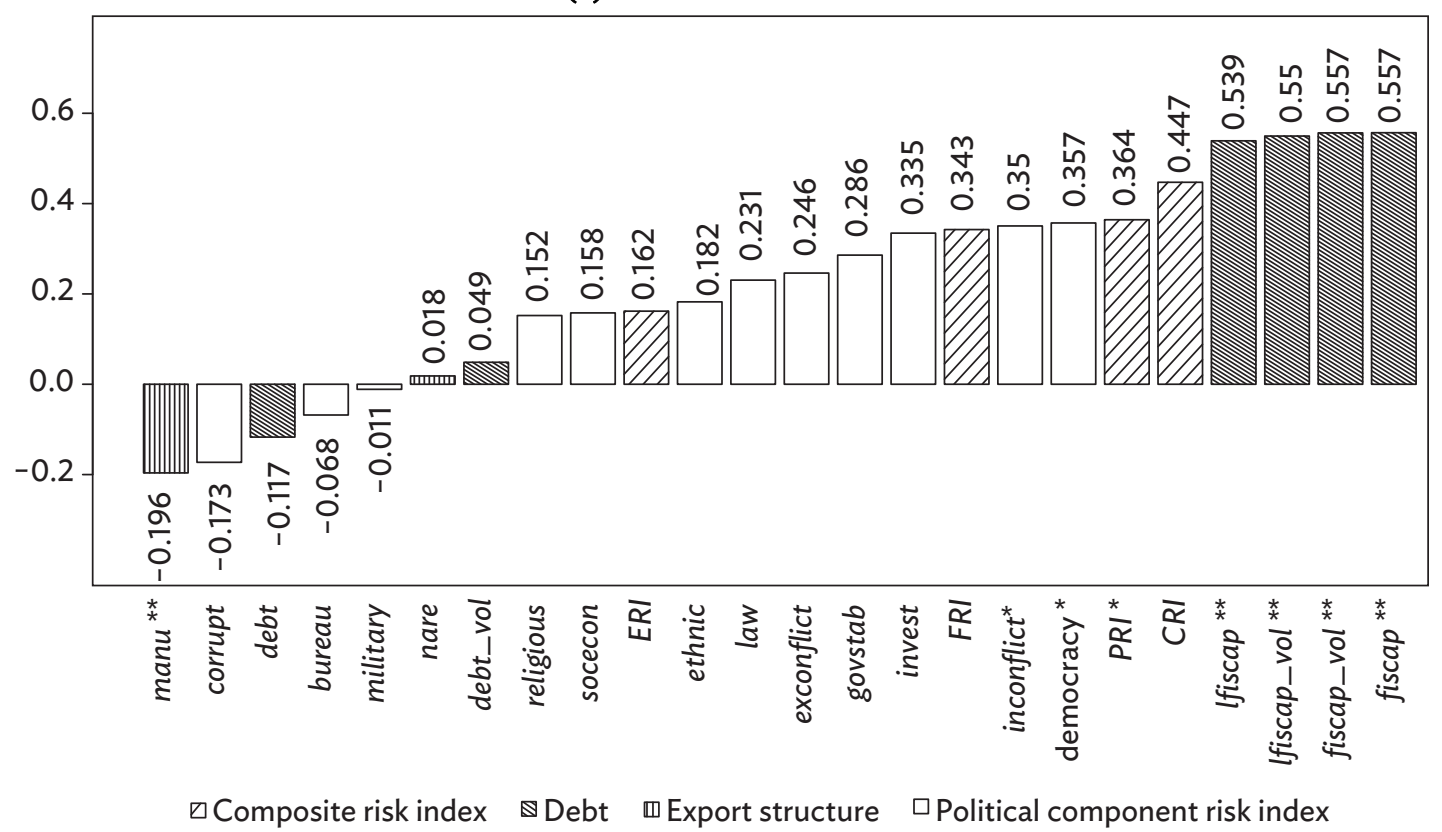

Notes: $\hat{\beta}_{G S}$ by country is estimated using the Prais-Winsten approach. The economic significance of each explanatory variable in each region is calculated by multiplying its corresponding standard deviation with its estimated coefficient from cross-country regression for that region to approximate the effect of its one standard deviation increase on the fiscal cyclicality. Countries are grouped according to World Bank regions. ${ }^{* *} p<0.05^{* *} p<0.01^{*} p<0.2$.

Source: Authors' calculation.

In East Asia and the Pacific, governance and institutional quality, as measured by most of the country risk indices, have large and negative effects on fiscal procyclicality. The exception is the external conflict index, which is not statistically significant. In Europe and Central Asia, manufacturing export share and institutional quality have the expected negative association with fiscal procyclicality. The public debt-GDP ratio, however, has a statistically significant and negative association with government-spending cyclicality; that is, a higher debt-GDP ratio is associated with less fiscal procyclicalicality. In Latin America and the Caribbean, better institutional quality, more stable politics, a smaller share of natural resource exports, and a lower public debt-GDP ratio are associated with lower government-spending procyclicality. The results for the Middle East and North Africa are intriguing. As expected, this region achieves good scores on some socioeconomic indices, and a few political stability variables are negatively associated with fiscal procyclicality. But the institutional quality variables of lower corruption, better bureaucracy quality, and higher democratic accountability are positively associated with fiscal procyclicality. Interestingly, there is some evidence of better institutional quality in Sub-Saharan Africa positively associated with procyclicality. But the positive association of the public debt-tax base ratio and negative association of the share of manufacturing exports with government-spending procyclicality are the most obvious in this region. 


\section{B. Fiscal Space in a Deteriorating Macroeconomic Environment}

\section{Rising Public Debt-Tax Base Ratio and Government-Spending Cyclicality by Region}

What would happen if there is an enduring rise in the global interest rate, thereby increasing the cost of borrowing and servicing public debt? To answer this, we looked at the economic significance of limited fiscal capacity on government-spending cyclicality, using the public debt-tax base ratio (Figure 5). We then calculated what would happen if fiscal capacity fell by $10 \%$ : specifically, $0.1^{*}$ (Regional-specific estimated coefficient of public debt-tax base ratio)*(Regional-specific public debt-tax base average ratio over the $1960-2016$ period). ${ }^{12}$

Figure 5, panel (a), shows the limited fiscal capacity, as measured by the average public debt-tax base ratio during 2010-2016. East Asia and the Pacific, and Middle East and North Africa, have lower fiscal capacities compared with Latin America and the Caribbean, Sub-Saharan Africa, and Europe and Central Asia. But Figure 5, panel (b), shows Sub-Saharan Africa is distinctly fragile fiscally, being exposed to large government-spending procyclicality if there is a deterioration in the macroeconomic environment and fiscal space. Based on the calculation, a 10\% decrease in fiscal capacity is associated with an upper bound of $5.6 \%$ increase in government-spending procyclicality.

\section{Figure 5: Economic Significance of Public Debt-Tax Base Ratio to Government-Spending Cyclicality $\widehat{\boldsymbol{\beta}}_{\mathrm{GS}}$ by Region}

(a) Actual average public debt-tax base ratio, 2010-2016



(b) Predicted economic significance of public debt-tax base ratio

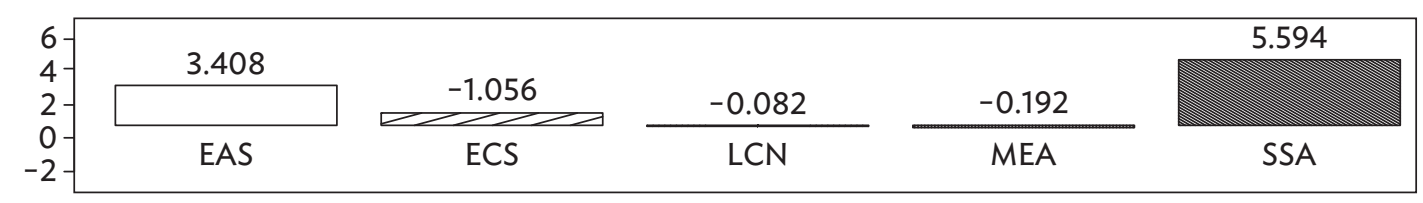

EAS = East Asia and the Pacific, ECS = Europe and Central Asia, LCN = Latin America and the Caribbean, MEA = Middle East and North Africa, SSA = Sub-Saharan Africa.

Notes: Panel (b) approximates the change of government spending cyclicality by region if the public debt-tax base ratio increases by $10 \%$, which is calculated by $0.1^{*}$ (Regional-specific estimated coefficient of public debt-tax base ratio)*(Actual regional-specific public debt-tax base average ratio over 1960-2016). Regional-specific estimated coefficient of public debt-tax base ratio is from the corresponding cross-sectional regression by region. $\hat{\beta}_{\mathrm{GS}}$ by country is estimated using the Prais-Winsten approach. Countries are grouped according to World Bank regions.

Source: Authors' calculation.

12 See Aizenman et al. (2018) for more results using another indicator for limited fiscal capacity: the ratio of public debt to 3year moving average tax base. 
Figure 6: Economic Significance of Public Debt-Tax Base Ratio to Government-Spending Cyclicality $\widehat{\boldsymbol{\beta}}_{\mathrm{GS}}$ by Country

(a) Actual average public debt-tax base ratio, 2010-2016

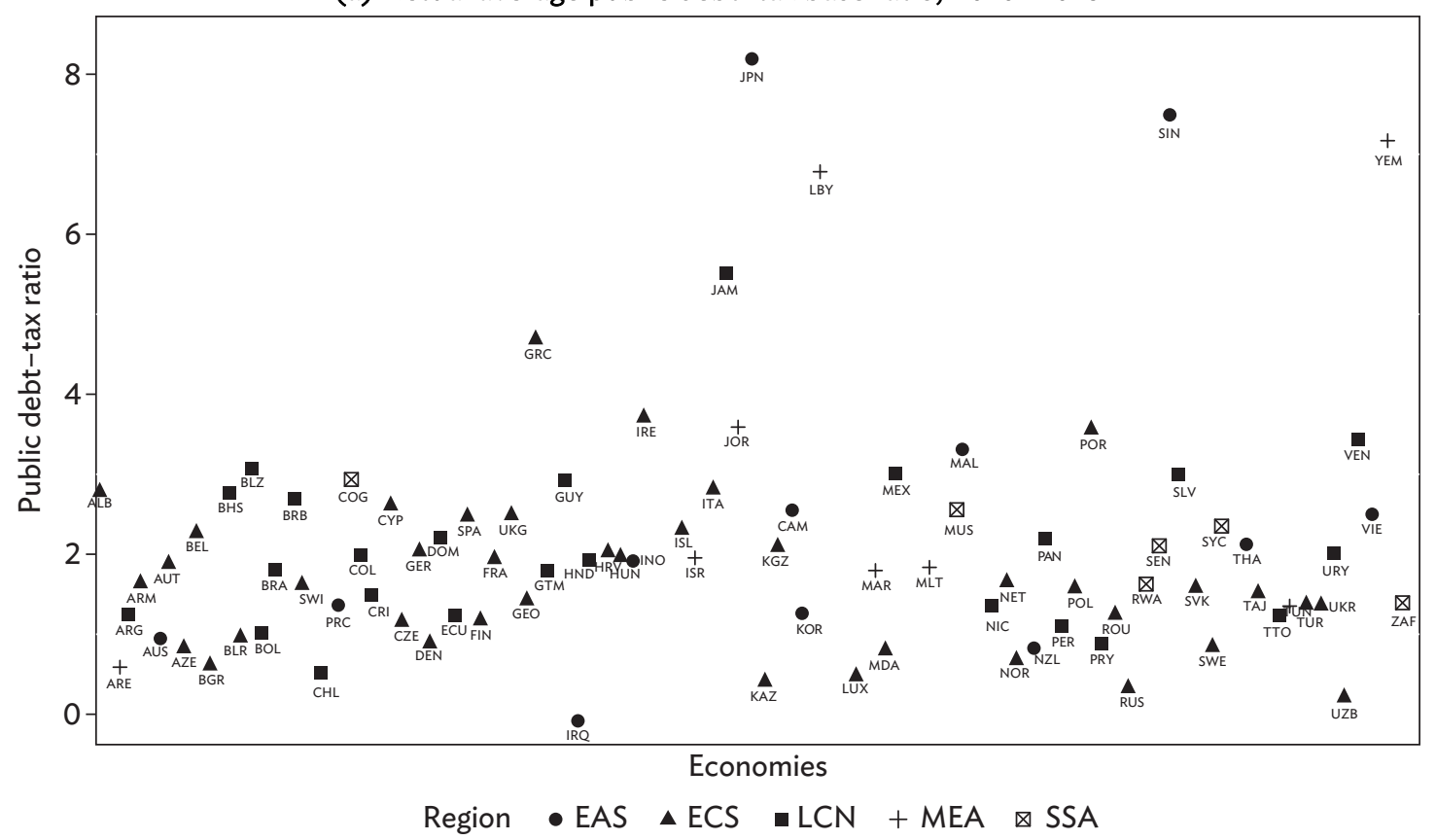

(b) Predicted economic significance of public debt-tax base ratio

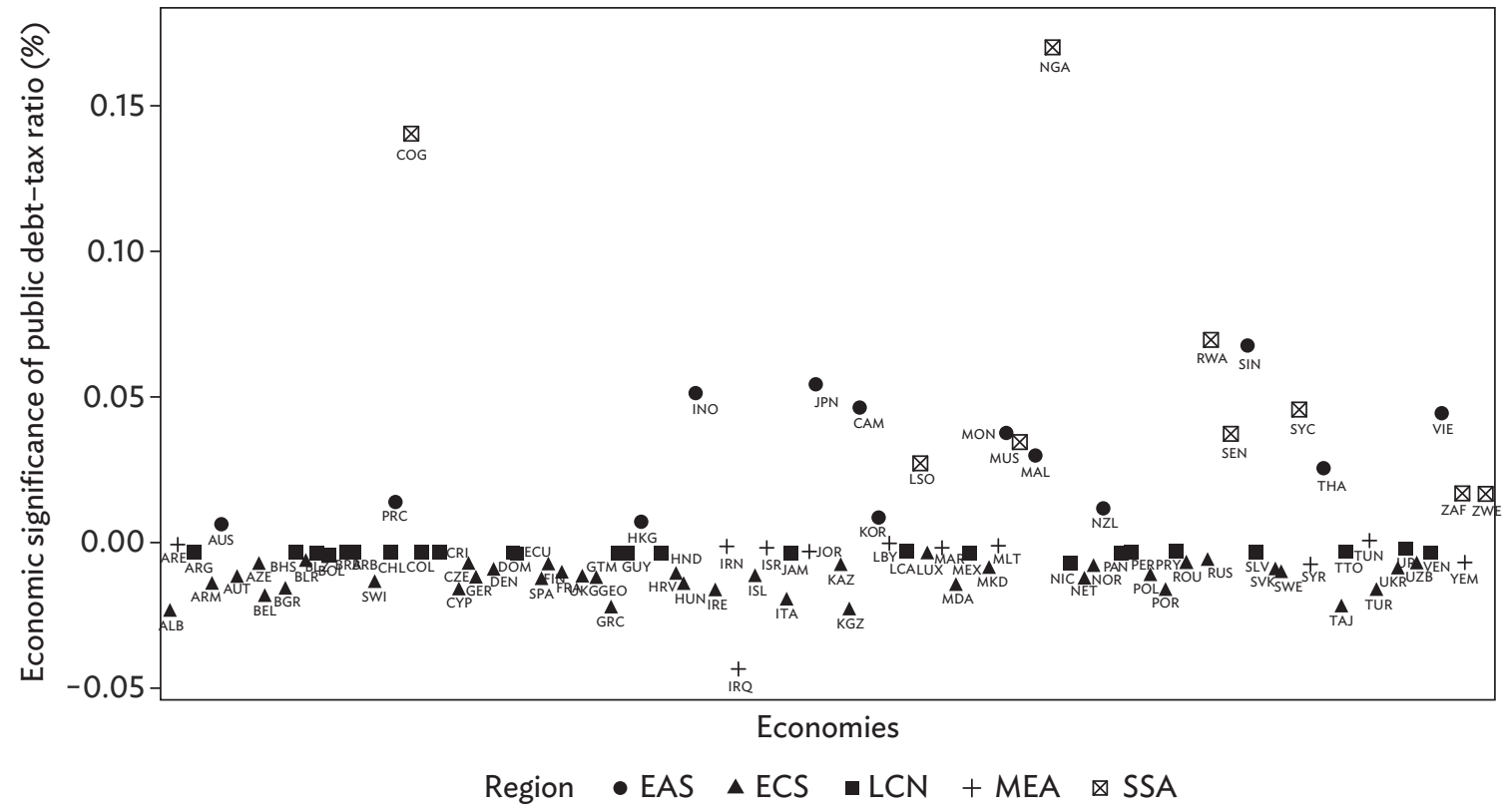

EAS = East Asia and the Pacific, ECS = Europe and Central Asia, LCN = Latin America and the Caribbean, MEA = Middle East and North Africa, SSA = Sub-Saharan Africa.

Notes: Panel (b) approximates the change of government spending cyclicality by country if the public debt-tax base ratio increases by $10 \%$, which is calculated by multiplying $0.1^{*}$ (Regional-specific estimated coefficient of public debt-tax base ratio)*(Actual country-specific public debt-tax base average ratio over 1960-2016). Regional-specific estimated coefficient of public debt-tax base ratio is from the corresponding crosscountry regression by region, which is used in place of a country-specific coefficient, because there is insufficient country data to estimate the second-step regression on a country-by-country basis. $\widehat{\beta}_{\mathrm{GS}}$ by country is estimated using the Prais-Winsten approach. Countries are grouped according to World Bank regions. The definition of the codes are in the Appendix.

Source: Authors' calculation. 


\section{Increase in Public Debt-Tax Base Ratio and Government-Spending Cyclicality by Country}

We calculate for each country the impact of deteriorating fiscal space. Specifically, $0.1^{*}$ (Countryspecific public debt-tax base ratio)* (Regional-specific estimated coefficient of public debt-tax base ratio) to estimate the economic significance of a $10 \%$ drop in fiscal capacity on a country basis to government-spending cyclicality. We use a regional-specific coefficient in place of a country-specific coefficient because of insufficient country data to estimate the second-step regression-that is, equation (2)- $\widehat{\beta}_{\mathrm{GS}}=\mathrm{f}$ (public debt-tax base ratio, control variables) -on a country basis. As shown in panel (a) of Figure 6, Greece, Jamaica, Japan, Libya, Singapore, and Yemen had the most limited fiscal capacity based on the 2010-2016 data, accumulating public debt that was 4 to 8 times larger than their tax bases. According to this calculation, shown in panel (b), fiscally fragile countries are mostly in Sub-Saharan Africa (Nigeria, the Democratic Republic of the Congo, Rwanda, and the Seychelles,) and a few cases in East Asia (Cambodia, Indonesia, Japan, and Viet Nam).

\section{Fiscal Cyclicality in Good Times versus Bad Times}

Recent studies point to the importance of understanding the asymmetry of fiscal cyclicality in good times compared with bad times. Alesina et al. (2017) use narrative-identified exogenous fiscal stabilizations, which are not supposed to be correlated with the economic cycle, to show that for 16 OECD countries, cuts in government spending and transfers are much less harmful than tax increases. Auerbach and Gorodnichenko (2017) show that for G-7 countries, government spending shocks do not lead to persistent increases in public debt-GDP ratios or costs of borrowing, especially during periods of economic weakness. Yet, we are concerned with both industrial and developing countries.

The estimated $\hat{\beta}$ 's from equation (1) have so far provided the cyclicality patterns of government spending. But we can delve further by separating the fiscal actions in good times from those in bad times. So as not to complicate our analysis with output-gap estimates and trend filtering, we define good times as periods with positive real GDP growth and bad times as those when real GDP contracted. We depict these effects in the following regression:

$$
\Delta \log R G S_{i t}=\alpha_{i}+\gamma_{i} * \Delta \log R G D P_{i t}+\lambda_{i} * D_{i t}+\theta_{i} * \Delta \log R G D P_{i t} * D_{i t}+v_{i t},
$$

where $D_{i t}=0$ if times are good (strong economic growth in country $i$ at time $t$ ), $D_{i t}=1$ if times are bad (weak economic growth), and $\theta_{i}$ tests the asymmetric response of government spending in bad times compared with good times for country $i$. To get the OLS and the Prais-Winsten estimators, we adopt the following regression models:

$$
\begin{gathered}
\Delta \log R G S_{i t}=\alpha_{i}+\gamma_{i} * \Delta \log R G D P_{i t}+u_{i t} \text { if } \mathrm{D}=0 \\
\Delta \log R G S_{i t}=\left(\alpha_{i}+\lambda_{i}\right)+\left(\gamma_{i}+\theta_{i}\right) * \Delta \log R G D P_{i t}+\omega_{i t} \text { if } \mathrm{D}=1
\end{gathered}
$$

\section{Fiscal Cyclicality During Good Times Versus Bad Times by Country}

Aizenman et al. (2018) presented findings for fiscal cyclicality (government spending and tax) by country for good times $(D=0)$ using Prais-Winsten and OLS estimators, and bad times $(D=1)$ using OLS estimators. Canada, the Kyrgyz Republic, the Republic of Korea, and Sweden were found to be fiscally countercyclical countries during good times according to the Prais-Winsten estimators. Note that the estimated coefficients from the OLS differ significantly from the Prais-Winsten estimators for 
many countries. There are many countries that are either more procyclical or acyclical in their government spending during bad times. But there are also countries that are more procyclical in good times, and there are countries that are more countercyclical in bad times. Essentially, we have a mixed bag of asymmetries in government-spending cyclicality patterns.

\section{Determinants of Fiscal Cyclicality During Good versus Bad Times}

To make sense of the country-specific asymmetry across good and bad times, we reestimate the determinants and find that the associations between government-spending procyclicality $\left(\widehat{\beta}_{\mathrm{GS}}\right)$ and explanatory variables during good times are largely similar to the baseline model. This is positively associated with limited fiscal capacity and its volatility, as well as the natural resource share of exports; and negatively associated with the manufacturing share of exports and country risks. ${ }^{13}$

Figure 7: Economic Significance of Variables to Government-Spending Cyclicality $\widehat{\boldsymbol{\beta}}_{\mathbf{G S}}$ in Good and Bad Times

(a) Government-spending cyclicality $\widehat{\boldsymbol{\beta}}_{\mathrm{GS}}$ in good times using Prais-Winsten estimates

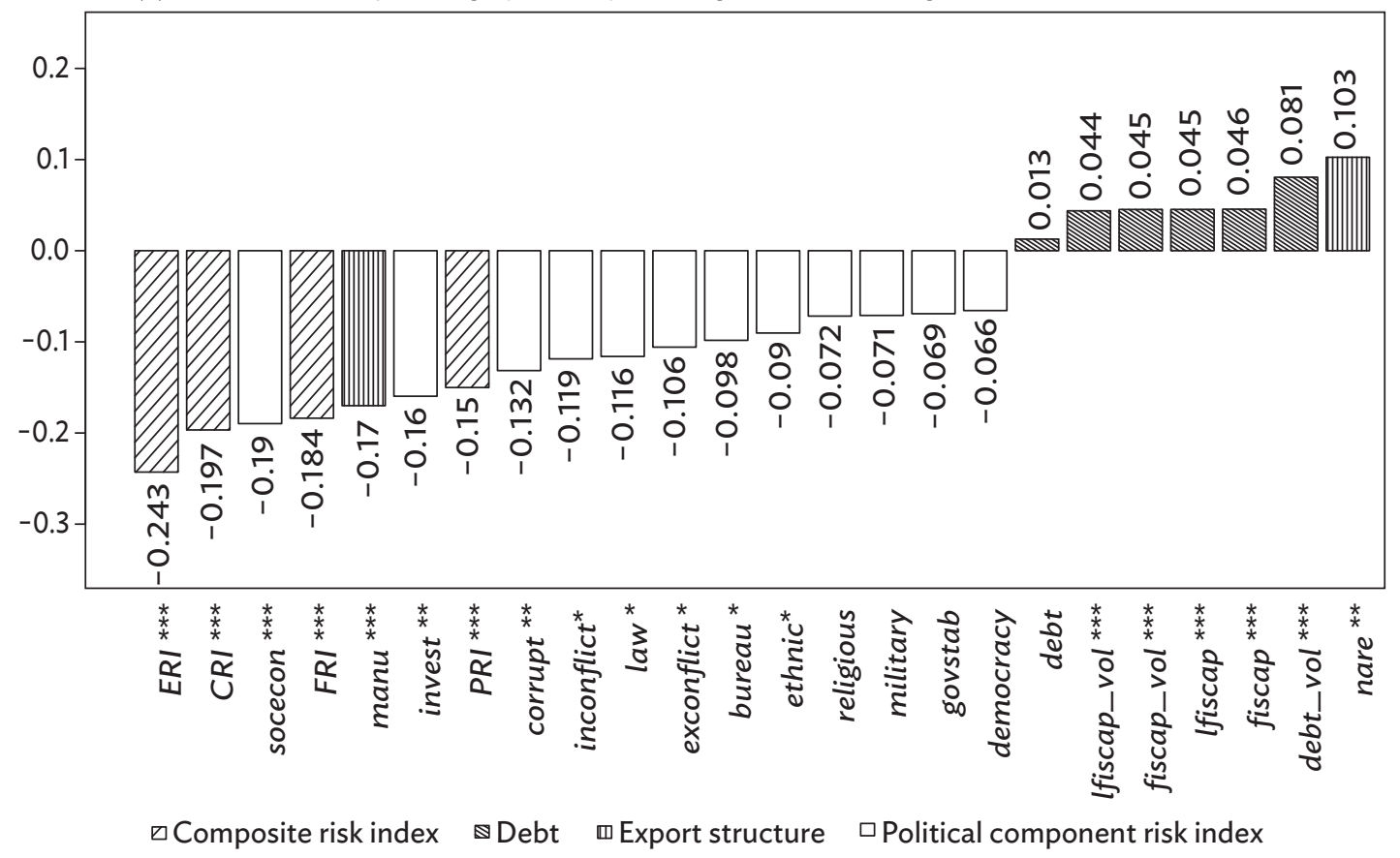

continued on next page

13 See Aizenman et al. (2018) for the detailed tabulation of these estimates. 
Figure 7 continued

(b) Government-spending cyclicality $\widehat{\boldsymbol{\beta}}_{\mathrm{GS}}$ in good times using ordinary least squares estimates

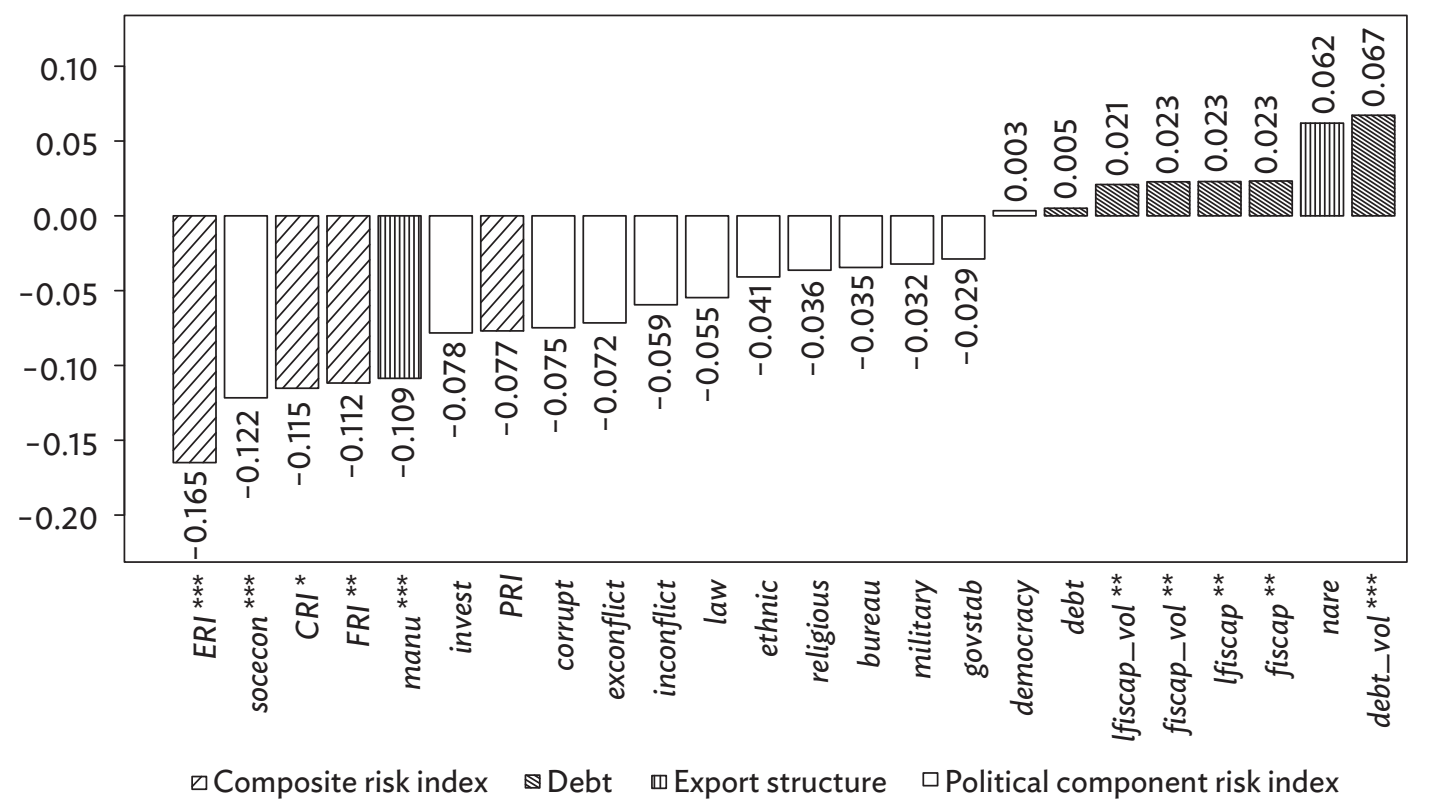

(c) Government-spending cyclicality $\widehat{\boldsymbol{\beta}}_{\mathrm{GS}}$ in bad times using ordinary least squares estimates

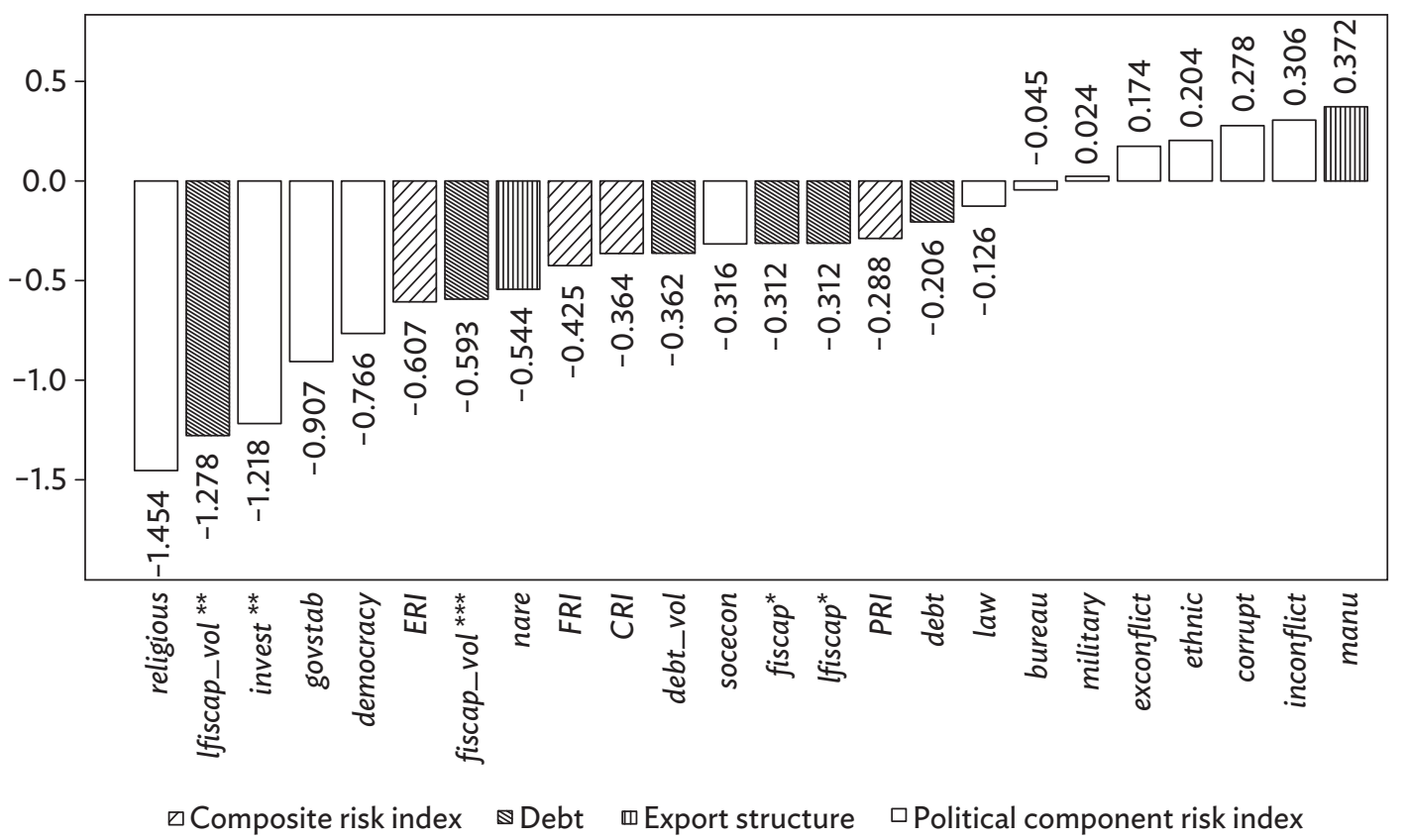

Notes: The economic significance of each explanatory variable is calculated by multiplying its standard deviation with its estimated coefficient to approximate the effect of its 1-standard deviation increase on the fiscal cyclicality. ${ }^{* *} p<0.05^{* *} p<0.01{ }^{*} p<0.2$. Source: Authors' calculation. 
The volatility of public debt is also positively associated with government-spending procyclicality in good times. For bad times, the volatility of limited fiscal capacity and investment profile are statistically significant and negatively associated with government-spending cyclicality. So, it seems that in bad times, public debt, tax base, and investment confidence play a larger role in government-spending cyclicality. Figure 7 summarizes the economic significance of the explanatory variables on government-spending cyclicality in good and bad times. Focusing on fiscal space, we note the asymmetry of its impact on government-spending cyclicality. Although smaller fiscal space is associated with higher fiscal procyclicality in good times (Figure 7, panels [a] and [b]), it is not statistically significant in bad times (Figure 7, panel [c]), implying that a more indebted government (relative to the tax base) spends more in good times and cuts back indifferently compared with lowdebt countries in bad times.

\section{Cyclicality of Government Spending with Capital Investment}

As noted in the discussion on the baseline, we find significant differences in government-spending cyclicality across the subperiods, as government spending includes capital investment. Using World Economic Outlook data from 1980 to 2016, spending becomes more procyclical over time. Using World Development Indicators from 1960 to 2016, however, spending becomes less procyclical over time. To examine the sensitivity of the empirical findings, we reestimate the two-step estimation for government spending defined as total expenditure plus the net acquisition of nonfinancial assets in the World Economic Outlook. Here, the net acquisition of nonfinancial assets equals gross fixed capital formation less consumption of fixed capital plus changes in inventories and transactions in other nonfinancial assets. We use the same set of controlling variables in the second step.

Based on the estimated country-specific $\widehat{\beta}_{\mathrm{GS}}$ over 1980-2016, government-spending cyclicality in Sub-Saharan Africa (0.94), and Latin America and the Caribbean (0.80), are among the highest. Higher-income regions are still characterized by a lower degree of government-spending procyclicality, while OECD countries are more countercyclical than non-OECD countries (Aizenman et al. 2018). Table 6 shows the estimation results on the determinants of government-spending procyclicality. Here, the public debt-GDP ratio and its volatility are significantly and positively associated with $\hat{\beta}_{\mathrm{GS}}$ as expected, but limited fiscal capacity (high public debt-tax base ratio) is no longer significant. The manufacturing export share remains negatively associated with fiscal procyclicality, but the natural resources export share is no longer significant. Institutional risks, including the composite risk index, economic risk index, government stability, socioeconomic conditions, corruption, and law and order are negatively associated with fiscal procyclicality, as in the baseline model. 
Fiscal Space and Increasing Fiscal Resilience | 27

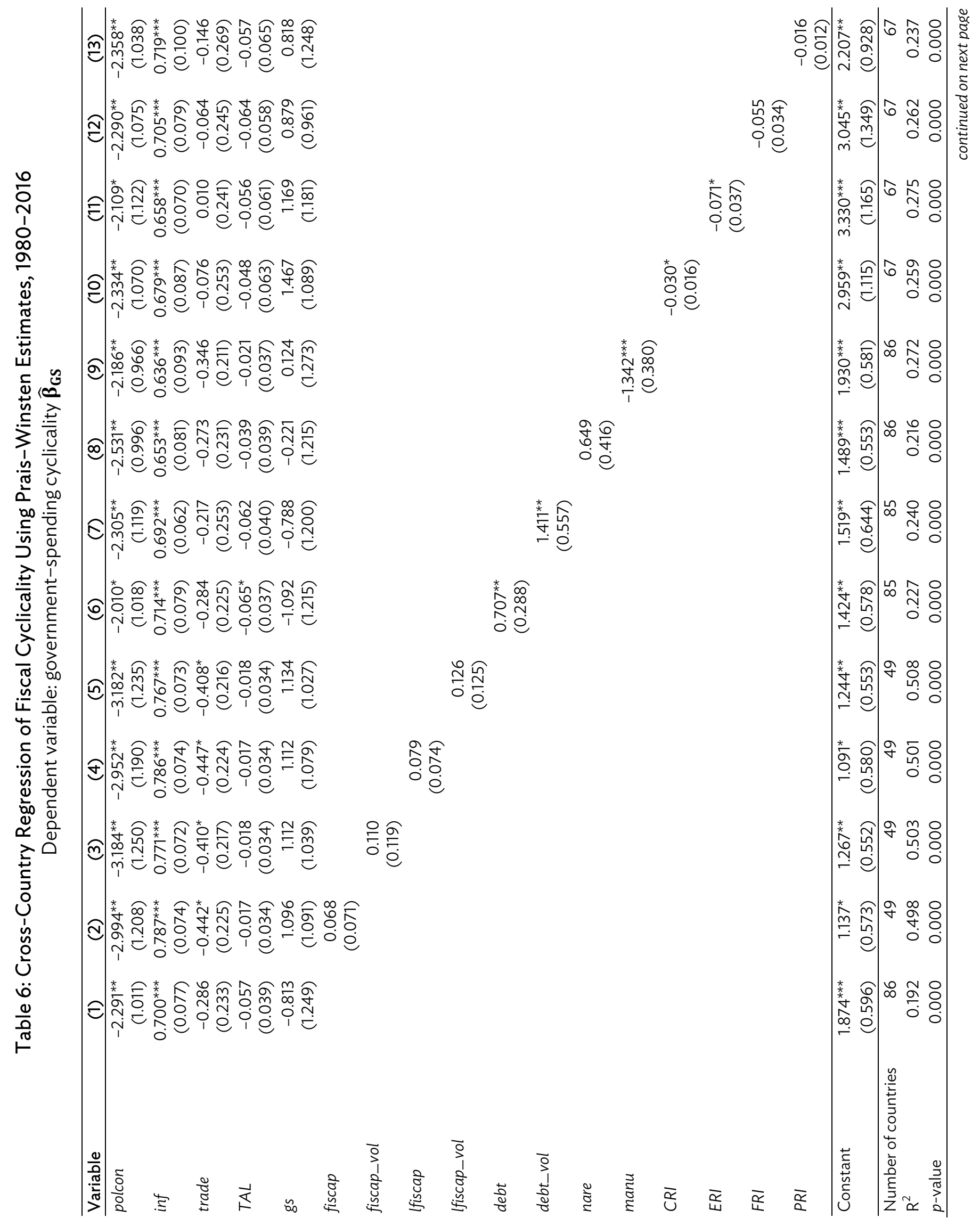




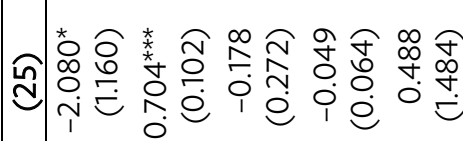

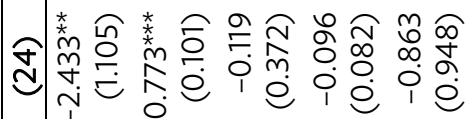

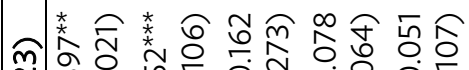

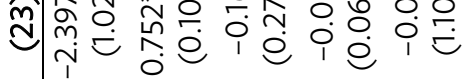

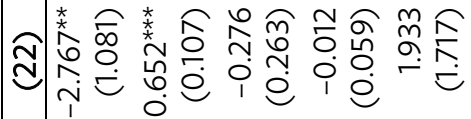

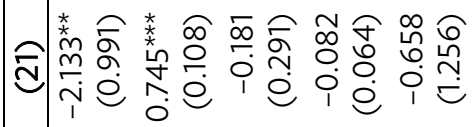

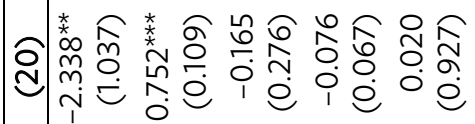

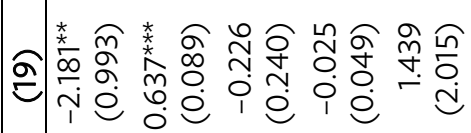

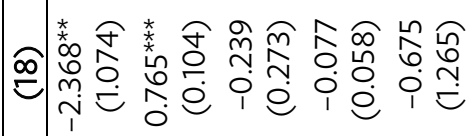

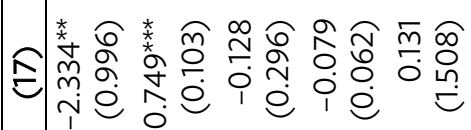

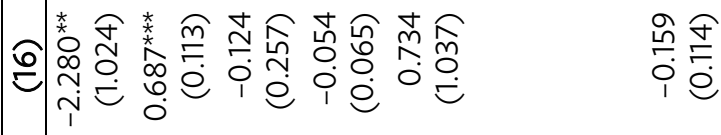

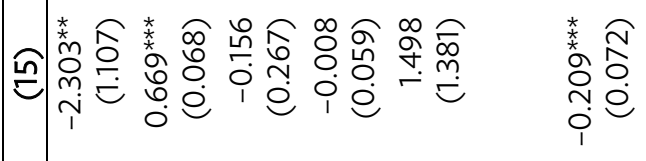

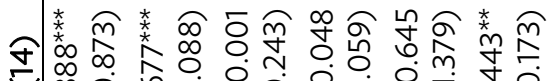

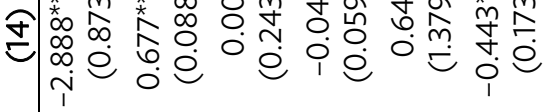

胥

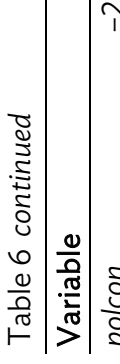

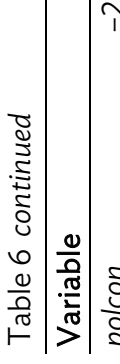

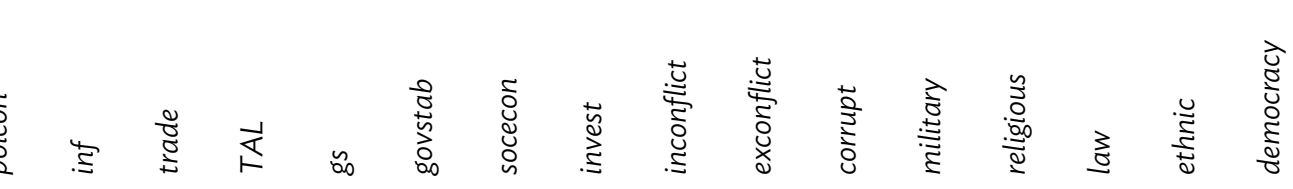

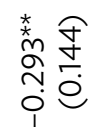

:

유요용

)

表琶

:

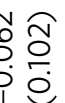

요ㅇㅛㅛ

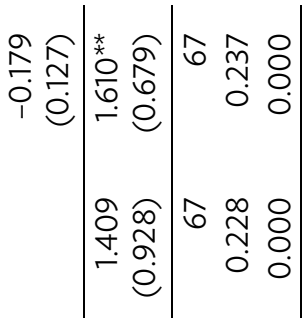

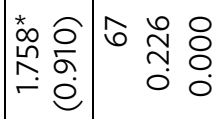

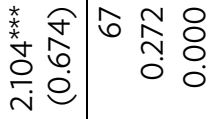

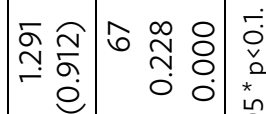

苾

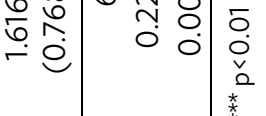

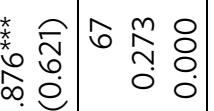

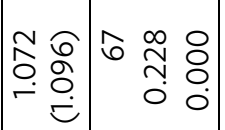

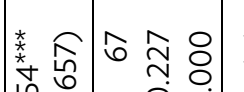

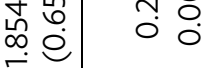

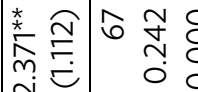

莠

în

荎

\%

+

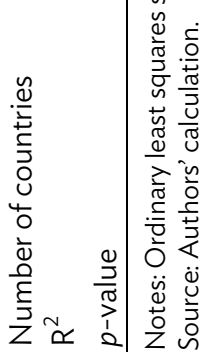


Based on the panel data estimation of $\widehat{\beta}_{\mathrm{GS}}$ using government spending data that includes capital expenditure, we confirm the ranking based on the time series estimation of $\widehat{\beta}_{\mathrm{GS}}$ that non-OECD countries are more fiscally procyclical than OECD ones (see the right-side panel in Table 3). Table 4, panel (b), confirms that lower-income countries have the highest level of government-spending procyclicality. We then rank the economic significance of the explanatory variables on governmentspending cyclicality. The country risks have negative and greater association with $\hat{\beta}_{\mathrm{GS}}$ than other variables, including public debt-GDP ratio and export structure.

Our findings on the cyclicality of government spending accounting for capital expenditure suggest that it may be useful to examine not only the size but also the composition of government expenditure (that is, health care, education, defense, and so on) to determine which expenditure components drive fiscal cyclicality. Because of heterogeneous populations and income inequality, it is quite likely that the composition of government spending is influenced by trade and financial openness, political economy considerations, the availability of social safety nets, and fiscal capacity. ${ }^{14}$

\section{E. Sovereign Wealth Funds and Government-Spending Cyclicality}

We close the empirical analysis by looking at the role of sovereign wealth funds on fiscal cyclicality. We estimate the following regression model:

$$
\begin{gathered}
\hat{\beta}_{i}=\alpha_{0}+\gamma_{k} * \operatorname{CONTROL}_{k i}+\rho * S W F_{i}+\delta_{1} * \operatorname{fiscap}_{i}+\delta_{2} *\left(S W F_{i} * \operatorname{fiscap}_{i}\right) \\
+\theta_{1} * C R I_{i}+\theta_{2} *\left(S W F_{i} * C R I_{i}\right)+\varepsilon_{i}
\end{gathered}
$$

where the dummy $S W F=1$ if the country has a sovereign wealth fund in operation starting at any point during 1960-2016, and $S W F=0$ if it does not. Focusing on the fiscal space and institutional risks, we include their interactions with the $S W F$ variable. We estimate equation (4) using weighted least squares, with real GDP (in 2010 US dollars) as the weight. Table 7 shows the estimation results for the entire review period, 1960-2016, and a subsample of good times; the estimates for bad times are qualitatively similar but statistically insignificant. The negative coefficients of $S W F$ interactions with the public debt-tax ratio and institutional quality suggest the negative impact of sovereign wealth funds. Their existence has a negative association with government-spending procyclicality. Essentially, the findings point to the benefit of investing in sovereign wealth funds as countercyclical fiscal buffers in good times to mitigate tax revenue shortfalls in bad times, thereby increasing the availability of countercyclical spending policy.

14 Shelton (2007) studies the size and composition of government spending across countries over 1970-2000. It is likely that the spending composition is time varying, especially after the global financial crisis and because of the growing concerns over income inequality in industrial and developing countries in recent years. 
Table 7: Sovereign Wealth Funds and Government-Spending Cyclicality Dependent variable: government-spending cyclicality $\widehat{\boldsymbol{\beta}}_{\mathbf{G S}}$

\begin{tabular}{|c|c|c|c|c|}
\hline \multirow[b]{2}{*}{ Variables } & \multicolumn{2}{|c|}{ Full Sample } & \multicolumn{2}{|c|}{ Good Times } \\
\hline & (1) & (2) & (3) & (4) \\
\hline \multirow[t]{2}{*}{ polcon } & -0.816 & -0.826 & -0.328 & -0.341 \\
\hline & $(0.751)$ & $(0.748)$ & $(0.671)$ & $(0.669)$ \\
\hline \multirow[t]{2}{*}{$\inf$} & -0.091 & -0.090 & -0.038 & -0.038 \\
\hline & $(0.080)$ & $(0.080)$ & $(0.060)$ & $(0.060)$ \\
\hline \multirow[t]{2}{*}{ trade } & 0.058 & 0.066 & 0.036 & 0.046 \\
\hline & $(0.132)$ & $(0.131)$ & $(0.146)$ & $(0.146)$ \\
\hline \multirow[t]{2}{*}{ TAL } & -0.004 & -0.004 & -0.001 & -0.000 \\
\hline & $(0.003)$ & $(0.003)$ & $(0.003)$ & $(0.003)$ \\
\hline \multirow[t]{2}{*}{ fiscap } & $0.121^{* * *}$ & & $0.102^{*}$ & \\
\hline & $(0.041)$ & & $(0.051)$ & \\
\hline \multirow[t]{2}{*}{ SWF $\times$ fiscap } & $-0.125^{* * *}$ & & $-0.103^{* *}$ & \\
\hline & $(0.041)$ & & $(0.051)$ & \\
\hline \multirow[t]{2}{*}{ lfiscap } & & $0.119^{* * *}$ & & $0.101^{* *}$ \\
\hline & & $(0.038)$ & & $(0.047)$ \\
\hline \multirow[t]{2}{*}{ SWF $\times$ lfiscap } & & $-0.125^{* * *}$ & & $-0.103^{* *}$ \\
\hline & & $(0.038)$ & & $(0.047)$ \\
\hline \multirow[t]{2}{*}{$C R I$} & $-0.019^{* *}$ & $-0.019^{* *}$ & $-0.016^{*}$ & $-0.017^{*}$ \\
\hline & $(0.008)$ & $(0.008)$ & $(0.009)$ & (0.009) \\
\hline \multirow[t]{2}{*}{$S W F \times C R I$} & $-0.046^{* * *}$ & $-0.046^{* * *}$ & $-0.023^{*}$ & $-0.023^{*}$ \\
\hline & $(0.011)$ & $(0.011)$ & $(0.013)$ & $(0.013)$ \\
\hline \multirow[t]{2}{*}{ Constant } & $1.778^{* * *}$ & $1.810^{* * *}$ & $1.593^{* *}$ & $1.623^{* *}$ \\
\hline & $(0.660)$ & $(0.653)$ & $(0.676)$ & $(0.670)$ \\
\hline Number of countries & 81 & 81 & 80 & 80 \\
\hline$R^{2}$ & 0.584 & 0.586 & 0.368 & 0.373 \\
\hline$p$-value & 0.000 & 0.000 & 0.000 & 0.000 \\
\hline
\end{tabular}

Notes: Weighted least squares with robust standard errors in parentheses. The weight is real gross domestic product (2010 US dollars) by country averaged over the full period in the full sample and over good times in the good times subsample. $\widehat{\beta}_{\mathrm{GS}}$ by country is estimated using the Prais-Winsten approach. Columns (1)-(2) use $\widehat{\beta}_{\mathrm{GS}}$ estimated in the full sample over 1960-2016, columns (3)-(4) use $\widehat{\beta}_{\mathrm{GS}}$ estimated for the good times subsample. Control variables are averaged over the corresponding periods. *** $p<0.01{ }^{* *} p<0.05^{*} p<0.1$.

Source: Authors' calculation. 


\section{CONCLUSIONS}

This paper shows a mixed fiscal environment in which more than half of the economies studied are characterized by limited fiscal space, and that their fiscal policies are either procyclical or acyclical. We find that, compared to the public debt-GDP ratio, the ratio of public debt to average tax base is a robust measure of limited fiscal space. On average, a more indebted government (relative to the tax base) spends more in good times and cuts back indifferently from a low-debt country in bad times. We find several economic and institutional variables associated with fiscal cyclicality. Furthermore, an enduring interest rate rise entails diminished fiscal space-a 10\% increase in the public debt-tax base ratio is associated with an upper bound of a $5.6 \%$ increase in government-spending procyclicality.

A limitation of our study is that, due to data constraints, we focus on general government and had to overlook the contribution of local and state government in a federal union system to cyclicality patterns. Chances are that controlling for these issues, we would find deeper procyclical and acyclical patterns. In the US, for example, state governments are frequently forced to apply procyclical expenditure patterns, which means cutting budgets during deep and prolonged recessions. It is widely agreed that procyclical fiscal policy should be mitigated as much as possible (IMF 2017). But there is no consensus on a practical approach to do this. For instance, what are the spending components that should be prioritized, and what are the fiscal rules that should be adopted to achieve an optimal degree of fiscal cyclicality?

Governments face various political pressures and socioeconomic targets (allocation efficiency, redistribution, debt stabilization, and so on), and prioritize them differently. Because of this, fiscal challenges are mostly context specific, without one size of policy response fitting all countries at all times. Our cross-country findings suggest that a better understanding is needed on the mixes of (i) the components of government spending, public debt, and tax base; (ii) fiscal policy, monetary policy, socioeconomics, and institutions; and (iii) the role of central banks and quasi-government entities (sovereign wealth funds and state-owned enterprises, for example). 


\section{APPENDIX: ECONOMY CODES}

\begin{tabular}{|c|c|c|c|c|c|c|c|}
\hline Code & Economy & Code & Economy & Code & Economy & Code & Economy \\
\hline AGO & Angola & DOM & Dominican Republic & LBY & Libya & SAU & Saudi Arabia \\
\hline ALB & Albania & DZA & Algeria & LCA & St. Lucia & SDN & Sudan \\
\hline ARE & United Arab Emirates & ECU & Ecuador & LSO & Lesotho & SEN & Senegal \\
\hline ARG & Argentina & EGY & Egypt & LUX & Luxembourg & SIN & Singapore \\
\hline ARM & Armenia & ERI & Eritrea & MAC & Macau, China & SLE & Sierra Leone \\
\hline ATG & Antigua and Barbuda & ETH & Ethiopia & MAL & Malaysia & SLV & El Salvador \\
\hline AUS & Australia & FIJ & Fiji & MAR & Morocco & SOL & Solomon Islands \\
\hline AUT & Austria & FIN & Finland & MDA & Moldova & SOM & Somalia \\
\hline AZE & Azerbaijan & FRA & France & MDG & Madagascar & SPA & Spain \\
\hline BAN & Bangladesh & GAB & Gabon & MEX & Mexico & SRI & Sri Lanka \\
\hline $\mathrm{BDI}$ & Burundi & GEO & Georgia & MKD & Macedonia, FYR & SUR & Suriname \\
\hline BEL & Belgium & GER & Germany & MLD & Maldives & SVK & Slovakia \\
\hline BEN & Benin & GHA & Ghana & MLI & Mali & SWE & Sweden \\
\hline BFA & Burkina Faso & GIN & Guinea & MLT & Malta & SWI & Switzerland \\
\hline BGR & Bulgaria & GMB & Gambia, The & MON & Mongolia & SWZ & Swaziland \\
\hline BHR & Bahrain & GNB & Guinea-Bissau & MOZ & Mozambique & SYC & Seychelles \\
\hline BHS & Bahamas & GNQ & Equatorial Guinea & MRT & Mauritania & SYR & Syrian Arab Republic \\
\hline $\mathrm{BHU}$ & Bhutan & GRC & Greece & MUS & Mauritius & TAJ & Tajikistan \\
\hline BLR & Belarus & GRD & Grenada & $\mathrm{MWI}$ & Malawi & TAP & Taipei,China \\
\hline BLZ & Belize & GTM & Guatemala & NAM & Namibia & TCD & Chad \\
\hline $\mathrm{BOL}$ & Bolivia & GUY & Guyana & NEP & Nepal & TGO & Togo \\
\hline BRA & Brazil & HKG & Hong Kong, China & NER & Niger & THA & Thailand \\
\hline BRB & Barbados & HND & Honduras & NET & Netherlands & TON & Tonga \\
\hline BRU & Brunei Darussalam & HRV & Croatia & NGA & Nigeria & TTO & Trinidad and Tobago \\
\hline BWA & Botswana & HUN & Hungary & NIC & Nicaragua & TUN & Tunisia \\
\hline CAF & $\begin{array}{l}\text { Central African } \\
\text { Republic }\end{array}$ & IND & India & NOR & Norway & TUR & Turkey \\
\hline CAM & Cambodia & INO & Indonesia & NZL & New Zealand & TZA & Tanzania \\
\hline CAN & Canada & IRE & Ireland & OMN & Oman & UGA & Uganda \\
\hline $\mathrm{CHL}$ & Chile & IRN & Iran & PAK & Pakistan & UKG & United Kingdom \\
\hline CIV & Côte d'Ivoire & IRQ & Iraq & PAN & Panama & UKR & Ukraine \\
\hline CMR & Cameroon & ISL & Iceland & PER & Peru & URY & Uruguay \\
\hline COD & Congo, Dem. Rep. of the & ISR & Israel & $\mathrm{PHI}$ & Philippines & USA & United States \\
\hline COG & Congo & ITA & Italy & PNG & Papua New Guinea & UZB & Uzbekistan \\
\hline $\mathrm{COL}$ & Colombia & JAM & Jamaica & POL & Poland & VAN & Vanuatu \\
\hline
\end{tabular}


34 | Appendix

\begin{tabular}{|c|c|c|c|c|c|c|c|}
\hline Code & Economy & Code & Economy & Code & Economy & Code & Economy \\
\hline COM & Comoros & JOR & Jordan & POR & Portugal & VCT & $\begin{array}{l}\text { St. Vincent and the } \\
\text { Grenadines }\end{array}$ \\
\hline CPV & Cabo Verde & JPN & Japan & PRC & $\begin{array}{l}\text { People's Republic of } \\
\text { China }\end{array}$ & VEN & Venezuela \\
\hline CRI & Costa Rica & KAZ & Kazakhstan & PRI & Puerto Rico & VIE & Viet Nam \\
\hline CUB & Cuba & KEN & Kenya & PRY & Paraguay & YEM & Yemen, Rep. \\
\hline CYP & Cyprus & $K G Z$ & Kyrgyz Republic & QAT & Qatar & ZAF & South Africa \\
\hline CZE & Czech Republic & KNA & St. Kitts and Nevis & KOR & Republic of Korea & ZMB & Zambia \\
\hline DEN & Denmark & KWT & Kuwait & ROU & Romania & ZWE & Zimbabwe \\
\hline DJI & Djibouti & LBN & Lebanon & RUS & Russian Federation & & \\
\hline DMA & Dominica & LBR & Liberia & RWA & Rwanda & & \\
\hline
\end{tabular}

Source: Authors' compilation. 


\section{REFERENCES}

Aizenman, Joshua, and Yothin Jinjarak. 2011. Income "Inequality, Tax Base and Sovereign Spreads." FinanzArchiv: Public Finance Analysis 4 (68): 431-44.

2012. "The Fiscal Stimulus of 2009-2010: Trade Openness, Fiscal Space, and Exchange Rate Adjustment." NBER International Seminar on Macroeconomics 8 (1): 301-42.

Aizenman, Joshua, Yothin Jinjarak, Hien Thi Kim Nguyen, and Donghyun Park. 2018. "Fiscal Space and Government-Spending and Tax-Rate Cyclicality Patterns: A Cross-Country Comparison, 1960-2016." NBER Working Paper No. 25012. Cambridge, MA: National Bureau of Economic Research.

Alesina, Alberto, Omar Barbiero, Carlo Favero, Francesco Giavazzi, and Matteo Paradisi. 2017. "The Effects of Fiscal Consolidations: Theory and Evidence." Working Paper. Cambridge, MA: Harvard University.

Alesina, Alberto, Filipe R. Campante, and Guido Tabellini. 2008. "Why is Fiscal Policy Often Procyclical?." Journal of the European Economic Association 6 (5): 1006-36.

Alesina, Alberto, Carlo Favero, and Francesco Giavazzi. 2015. "The Output Effect of Fiscal Consolidation Plans." Journal of International Economics 96: S19-S42.

Auerbach, Alan J. 2011. "Long-Term Fiscal Sustainability in Major Economies." BIS Working Paper No. 361. Basel: Bank for International Settlements.

Auerbach, Alan J., and Yuriy Gorodnichenko. 2017. "Fiscal Stimulus and Fiscal Sustainability." NBER Working Paper No. 23789. Cambridge, MA: National Bureau of Economic Research.

Budina, Nina, Tidiane Kinda, Andrea Schaechter, and Anke Weber. 2012. "Fiscal Rules at a Glance: Country Details from a New Dataset." IMF Working Paper No. 12/23. Washington, DC: International Monetary Fund.

Chinn, Menzie D., and Hiro Ito. 2006. "What Matters for Financial Development? Capital Controls, Institutions, and Interactions." Journal of Development Economics. 81 (1): 163-92.

Frankel, Jeffrey A. 2011. "A Solution to Fiscal Procyclicality: The Structural Budget Institutions Pioneered by Chile." Journal Economía Chilena 14 (2): 39-78.

Frankel, Jeffrey A., Carlos A. Végh, and Guillermo Vuletin. 2013. "On Graduation from Fiscal Procyclicality." Journal of Development Economics 100 (1): 32-47.

Gavin, Michael, Ricardo Hausmann, Roberto Perotti, and Ernesto Talvi. 1996. "Managing Fiscal Policy in Latin America and the Caribbean: Volatility, Procyclicality, and Limited Creditworthiness." IDB Working Paper No. 326. Washington, DC: Inter-American Development Bank.

Henisz, Witold J. 2002. "The Institutional Environment for Infrastructure Investment." Industrial and Corporate Change 11 (2): 355-89. 
Ilzetzki, Ethan, Enrique G. Mendoza, and Carlos A. Végh. 2013. "How Big (Small?) Are Fiscal Multipliers?" Journal of Monetary Economics 60 (2): 239-54.

Ilzetzki, Ethan, and Carlos A. Végh. 2008. "Procyclical Fiscal Policy in Developing Countries: Truth or Fiction?” NBER Working Paper No. 14191. Cambridge, MA: National Bureau of Economic Research.

International Monetary Fund (IMF). 2016. Assessing Fiscal Space: An Initial Consistent Set of Considerations. Washington, DC.

_ 2017. "A Greater Role for Fiscal Policy." In Fiscal Monitor: Achieving More with Less. Washington, DC.

2018. Fiscal Monitor: Capitalizing on Good Times. Washington, DC.

Jordà, Òscar, Moritz Schularick, and Alan M. Taylor. 2013. "When Credit Bites Back." Journal of Money, Credit and Banking 45 (S2): 3-28.

Kaminsky, Graciela L., Carmen M. Reinhart, and Carlos A. Végh. 2004. "When It Rains, It Pours: Procyclical Capital Flows and Macroeconomic Policies." NBER Macroeconomics Annual 19: 11-53.

Lane, Philip R. 2003. "The Cyclical Behaviour of Fiscal Policy: Evidence from the OECD." Journal of Public Economics 87 (12): 2661-75.

Leeper, Eric M., Nora Traum, and Todd B. Walker. 2017. "Clearing Up the Fiscal Multiplier Morass." American Economic Review 107 (8): 2409-54.

Minsky, Hyman P. 1992. "The Financial Instability Hypothesis.” Working Paper No. 74. New York: Jerome Levy Economics Institute of Bard College.

Ostry, Jonathan David, Atish R. Ghosh, Jun I. Kim, and Mahvash S. Qureshi. 2010. "Fiscal Space.” IMF Staff Position Note SPN/10/11. Washington, DC: International Monetary Fund.

Rajan, Raghuram G. 2006. "Has Finance Made the World Riskier?” European Financial Management 12 (4): 499-533.

Ramey, Valerie A., and Sarah Zubairy. 2018. "Government Spending Multipliers in Good Times and in Bad: Evidence From US Historical Data.” Journal of Political Economy 126 (2): 850-901.

Schularick, Moritz, and Alan M. Taylor. 2012. "Credit Booms Gone Bust: Monetary Policy, Leverage Cycles, and Financial Crises, 1870-2008.” American Economic Review 102 (2): 1029-61.

Shelton, Cameron A. 2007. "The Size and Composition of Government Expenditure." Journal of Public Economics 91 (11-12): 2230-60.

Végh, Carlos A., and Guillermo Vuletin. 2015. "How Is Tax Policy Conducted over the Business Cycle?" American Economic Journal: Economic Policy 7 (3): 327-70.

Woo, Jaejoon. 2009. "Why Do More Polarized Countries Run More Procyclical Fiscal Policy?" Review of Economics and Statistics 91 (4): 850-70. 


\section{Fiscal Space and Increasing Fiscal Resilience}

This paper compares fiscal cyclicality across advanced and developing economies in terms of geography and income levels from 1960 to 2016. It identifies factors that explain government spending and tax-policy cyclicality. On average, a more indebted government spends more in good times and cuts back spending indifferently compared with low-debt economies in bad times. The sovereign wealth funds of economies have a countercyclical effect in our estimation. The analysis depicts a significant economic impact of an interest rate rise on fiscal space: a 10\% increase in the public debt-tax base ratio is associated with an upper bound of a $5.6 \%$ increase in government-spending procyclicality.

\section{About the Asian Development Bank}

ADB is committed to achieving a prosperous, inclusive, resilient, and sustainable Asia and the Pacific, while sustaining its efforts to eradicate extreme poverty. Established in 1966, it is owned by 68 members49 from the region. Its main instruments for helping its developing member countries are policy dialogue, loans, equity investments, guarantees, grants, and technical assistance. 